University of Michigan Law School University of Michigan Law School Scholarship Repository

1995

\title{
How to Think about the Federal Commerce Power and Incidentally Rewrite United States v. Lopez
}

Donald H. Regan

University of Michigan Law School, donregan@umich.edu

Available at: https://repository.law.umich.edu/articles/340

Follow this and additional works at: https://repository.law.umich.edu/articles

Part of the Commercial Law Commons, Constitutional Law Commons, Courts Commons, Legislation Commons, and the Supreme Court of the United States Commons

\section{Recommended Citation}

Regan, Donald H. "How to Think about the Federal Commerce Power and Incidentally Rewrite United States v. Lopez (Symposium: Reflections on United States v. Lopez)." Mich. L. Rev. 94, no. 3 (1995): 554-614.

This Symposium is brought to you for free and open access by the Faculty Scholarship at University of Michigan Law School Scholarship Repository. It has been accepted for inclusion in Articles by an authorized administrator of University of Michigan Law School Scholarship Repository. For more information, please contact mlaw.repository@umich.edu. 


\title{
HOW TO THINK ABOUT THE FEDERAL COMMERCE POWER AND INCIDENTALLY REWRITE UNITED STATES v. LOPEZ
}

\author{
Donald H. Regan*
}

Almost sixty years after the "revolution" of 1937, we still do not have an adequate theory of the commerce power. The Court was right to abandon the theory of dual federalism epitomized by Carter v. Carter Coal Co. ${ }^{1}$ and it has got the right results in the major cases decided since then. But our post-1937 theory, whether before or after Lopez, is a mess. On the one hand, we have a collection of doctrinal rules that, if we take them seriously, allow Congress to do anything it wants under the commerce power. On the other hand, we continue to pay lip service to the idea that Congress's power is limited. Not only is our theory self-contradictory in this way, but the particular rules we have developed, and the way we apply them, cannot stand up to reflection about why we have the federal government and what it ought to be able to do.

Lopez is an occasion to pause and take stock. The Court caught the nation's attention - and presumably Congress's - by striking down a law as beyond the commerce power for the first time in sixty years. I do not think Lopez is likely to inaugurate a major change in the Court's inclination to uphold federal legislation. Justice Kennedy, speaking also for Justice O'Connor, makes clear in his concurrence that for him Lopez itself is a hard case, ${ }^{2}$ and Justice Rehnquist, writing for the Court, shows no sign of any intention to overturn the major Commerce Clause precedents since 1937.3 Still, this is an appropriate moment to ask where we ought to go from here.

* William W. Bishop, Jr., Collegiate Professor of Law and Professor of Philosophy, University of Michigan. A.B. 1963, Harvard; LL.B. 1966, University of Virginia; M.Phil. (Econ.) 1968, Oxford University; Ph.D. (Phil.) 1980, University of Michigan. - Ed. For comments and discussion on an earlier draft, I am grateful to Fred Schauer, Terry Sandalow, and the members of the Columbia Legal Theory Workshop.

1. 298 U.S. 238 (1936).

2. See United States v. Lopez, 115 S. Ct. 1624, 1634 (1995) (Kennedy, J., concurring).

3. See $115 \mathrm{~S}$. Ct. at $1626-34$. 
I am inclined to think the result in Lopez is correct, though it is not my main object to establish that. Even if the result is right, the opinion of the Court is unsatisfactory. Justice Rehnquist's distinction between commercial and noncommercial activities that affect commerce is an unsupported and ill-considered gloss on an already misguided theory. Justice Kennedy's opinion is an improvement, but it still takes too much of current thinking for granted.

If we are prepared to rethink more fundamentally, we can produce a theory of the commerce power that is internally consistent, that is faithful to the general intention of the Framers, that does no more damage to the text of the Commerce Clause than our current theory, that justifies the results - though not all of the arguments - in the major commerce power precedents, and that embodies an attractive conception of our federalism. Such a theory should appeal to originalists and believers in an evolving tradition alike.

My double goal, then, is to increase dissatisfaction with our existing Commerce Clause doctrine and theory, and to suggest a revised version to put in its place. My revised theory is not elaborated in every detail; I offer no mechanical test for the constitutionality of federal legislation. But it is a start. If I succeed in my first goal, I shall welcome collaboration on the second.

\section{INTRODUCTION TO THE REVISED THEORY}

The kernel of my positive suggestion is so obvious that I would be embarrassed to offer it, if it did not seem necessary that someone should: when we are trying to decide whether some federal law or program can be justified under the commerce power, we should ask ourselves the question, "Is there some reason the federal government must be able to do this, some reason why we cannot leave the matter to the states?" Federal power exists where and only where there is special justification for it - what sort of justification, it is my project to explain.

This idea is embodied in the sixth of the Virginia Resolutions, approved by the Constitutional Convention on July 17, 1787, in the following form:

That the National Legislature ought to possess the Legislative Rights vested in Congress by the Confederation; and moreover, to legislate in all cases for the general interests of the union, and also in those to which the States are separately incompetent, or in which the harmony 
of the United States may be interrupted by the exercise of individual Legislation. ${ }^{4}$

Of course, this language did not find its way into the Constitution. The Committee of Detail replaced this general description of national legislative power with a lengthy enumeration of specific powers, ${ }^{5}$ which developed into the eighteen clauses of Article I, Section 8. But there is no reason to think the Committee of Detail was rejecting the spirit of the Resolution when they replaced it with an enumeration. They may have thought they were doing nothing more than unfolding the implications of the general language. They may have meant to guard against overexpansive interpretation of the Resolution's vague, or at least abstract, language. They may have been motivated by stylistic considerations. ${ }^{6}$ If the Committee was worried about the broad language of the Resolution, it is an irony indeed that later times have relied on the Committee's language to justify some exercises of the commerce power that are plainly beyond the spirit of the "vague" original."

The Virginia Resolution is not part of the Constitution, and I should therefore point out that I do not rely on it for any proposition that we could not infer from the text of the Constitution itself. The mere fact of an enumeration of powers makes it clear that the federal government's powers are meant to be limited. Furthermore, if we tried to figure out from the specific grants what the principle of inclusion was, we would surely come up with something like the Resolution. Nor does the enumeration make the question of the principle of inclusion irrelevant; we are forced to consider the question as we try to interpret the vaguer of the grants of power, like the Commerce Clause. The actual Resolution confirms what the text suggests about the principle underlying the enumeration, and gives us time-honored language to embody it.

Attending to the idea embodied in the Virginia Resolution will tend to narrow somewhat our present view of the commerce power. But my main object is not to narrow; it is to put our Commerce Clause jurisprudence on a reasonable footing. I have no desire to

4. Notes of Debates in the Federal Convention of 1787 Reported by James Madison 380 (W.W. Norton \& Co. ed., 1966) [hereinafter Notes of DEBATEs].

5. See Draft Constitution by the Committee of Detail, art. VII, $\$ 1$ (Aug. 6, 1787), reprinted in Notes of DeBATES, supra note 4, at 389-90.

6. If we assume they were not going to have in the final Constitution of the United States a clause incorporating by reference elements of the Articles of Confederation, then some enumeration was unavoidable. And if some powers were enumerated, it might have seemed more satisfactory to enumerate all.

7. See, for example, the discussion of the "toll-gate" power, infra notes 93-95 and accompanying text. 
take us back to the specific ideas of the Framers about what the federal government should do in 1787, when the economy and the nation were very different. I do not even want to take us back to 1936. In my opinion, the great federal regulatory programs of the New Deal era and beyond are all easily defensible, at least in their broad outlines. There have been excesses, both around the edges of some of those programs and in such frolics as the Gun-Free School Zones Act, ${ }^{8}$ but I am far from being an opponent of federal power. Indeed, having a better theory of the commerce power than we currently have would be our best defense - insofar as constitutional ideas matter at all - against those who really do seek radical limitations on federal power. It is the internal inconsistency of existing Commerce Clause theory, and the downright silliness of some of the doctrines, that make it seem as if programs that have become part of the fabric of our lives might still be in danger from changes in the personnel of the Court.

So, my suggestion is that in thinking about whether the federal government has the power to do something or other, we should ask what special reason there is for the federal government to have that power. What reason is there to think the states are incapable or untrustworthy? I propose to elaborate this suggestion largely by looking at specific cases to see what sorts of justification for federal power seem to have force in light of our history and the spirit of our institutions. In most of the great Commerce Clause cases, appropriate justifications are easily identified, even if the Court failed to identify them adequately; but in some cases that have become important precedents, the justifications are harder to find, and much of what is offered by the Court as justification is transparently inadequate. 9

Beyond illustrating my approach, I shall make no other effort to explain why we should adopt it. In particular, I am not going to offer any general discussion of the point or value of federalism. The idea of the states as laboratories where different approaches to dealing with widespread problems can be tried out ${ }^{10}$ is valuable and important; but if offered as the principal argument for federalism, it suggests too strongly that there is a single best approach to each problem and that once experiment has discovered the best ap-

8. 18 U.S.C. $\$ \S 921-22,924$ (1988).

9. See, for example, the discussion of Katzenbach v. McClung, 379 U.S. 294 (1964), infra section III.B.3.

10. See United States v. Lopez, 115 S. Ct. 1624, 1641 (1995) (Kennedy, J., concurring); New State Ice Co. v. Liebmann, 285 U.S. 262, 311 (1932) (Brandeis, J., dissenting). 
proach, all states can be expected to adopt it (so why not just adopt it at the federal level?). A newer argument, that we must limit the federal government's commandeering of state political institutions in order to maintain political accountability, ${ }^{11}$ is also important, but it is relevant only to a narrow aspect of the problem of defining the federal power. My own simpleminded view about the value of federalism is that, other things being equal, the states are entitled to be different - to have different views about the best solutions to their problems and even to have different views about what is a problem and what is not. Other things being equal, state differences should be protected. This is partly a matter of promoting political responsiveness and individual choice, and partly just a belief in the value of variety. Our national culture is already too homogenized to expect great differences between the states, but what cultural differences still remain should not be further eroded by central legislation without good reason. ${ }^{12}$

Of course, if I offer no more defense of federalism than this, some readers will conclude I am the prisoner of an outmoded idea. It is a common view among constitutional law scholars that we should abandon the idea of limits on federal power. We have become a unitary nation with an omnicompetent central government, and we should just admit it. ${ }^{13}$

Perhaps this is the best approach in the end. Certainly it achieves an internally consistent Commerce Clause theory that accommodates the major post-1937 precedents. But it involves discarding an idea that was central to our constitutional tradition for a century and a half, ${ }^{14}$ and that the Supreme Court is not yet ready to abandon. Even Justice Breyer, in an opinion signed by all four dissenters, argues that his approach does not subvert the idea of limits on federal power. ${ }^{15}$ In my view, we should not give up on the idea

11. See New York v. United States, 505 U.S. 144 (1992); Andrzej Rapaczynski, From Sovereignty To Process: The Jurisprudence of Federalism After Garcia, 1985 Sup. Cr. REv. 341. See my discussion infra notes $123-25$ and accompanying text.

12. My reasons for not attempting a fuller discussion of federalism are manifested in Larry Kramer's 76-page project description for a future study of federalism, Larry Kramer, Understanding Federalism, 47 VAND. L. Rev. 1485 (1994).

13. Terry Sandalow has pressed this point upon me in conversation. See generally also 1 Bruce Ackerman, We The People: Foundations (1991).

14. Alan Hyde has suggested to me that the Reconstruction Amendments completely recast state-federal relations and undermined the idea of limits on federal power in favor of the states. That seems to me an overstatement. The Reconstruction Congresses amended the Constitution; they did not rewrite or replace it. Neither explicitly nor implicitly did they abandon the idea of limits on the federal power. Indeed, they added to the specific grants of power, which hardly comports with the idea that they established a unitary government.

15. See, United States v. Lopez, 115 S. Ct. 1624, 1661-62 (1995) (Breyer, J., dissenting). 
of limits until we have made a serious attempt to see what the Framers' idea, as summarized in the Virginia Resolution, comes to in a modern context.

Some scholars would suggest that the Court abandoned the idea of a limited federal power in 1937, or soon thereafter, and that it has just been unwilling to say so. This requires us to regard generations of Supreme Court Justices as hypocritical, or at best selfdeceived. I should prefer to regard them as torn - especially Justice Roberts in the crucial years of 1936 and 1937 - between, on the one hand, the obvious need from the point of view of both national and state interests for a more permissive theory than that of Carter Coal and, on the other hand, the apparent inability of contemporary constitutional thinking to produce an alternative theory that accommodated those needs without abandoning all limits. The Court definitively rejected Carter Coal and "dual federalism" in 1937. But that is not to say they rejected the idea of limits, even if they lacked a theory that maintained them. If the idea of limits has been lost, notwithstanding the contrary assertions of the Court, it has happened more recently than 1937, and gradually, through accident and inattention and occasional prevarication. ${ }^{16}$ It is not too late to reverse the slide.

Incidentally, if my suggestions for a revised Commerce Clause theory are accepted, that need not lead to a significantly more activist Court in this area in the long run. In the short run, it might well lead to a few more cases like Lopez. But under my view as under existing theory, the question whether some statute is within the federal power often involves empirical questions about which the Court should give Congress considerable leeway. So I am not merely suggesting how courts should think about the commerce power. I am suggesting how Congress should think about it - how I hope a conscientious Congress can be persuaded to think about it by very occasional judicial intervention. ${ }^{17}$ Cynics may doubt that Congress can be persuaded to enforce on itself limitations on its own power. But I have not given up on the conscience of Congress. In recent years, Congress's conscience has not been tested. The Court's doctrine has allowed Congress to do in good conscience anything it pleased.

16. See infra note $\mathbf{1 3 0}$ and accompanying text.

17. As my choice of words suggests, one of my all-time favorite law review articles is Paul Brest, The Conscientious Legislator's Guide to Constitutional Interpretation, 27 STAN. L. REv. 585 (1975). 


\section{Current Doctrine, AND the Opinions in LOPEZ}

Before I elaborate further the revised theory, I want to pause to do two things. First, I shall give a rapid summary of current Commerce Clause doctrine, for purposes of comparison. The summary will ignore Lopez, which for the moment has not so much changed the situation as confused it; it will also ignore the New York $v$. United States ${ }^{18}$ problem of when the federal government has improperly commandeered state political institutions. Then I shall look quickly at the principal opinions in Lopez to explain why they are unsatisfactory and why Justice Kennedy's is least so.

\section{A. Current Commerce Clause Doctrine}

Current doctrine about the extent of the federal commerce power can be summarized in the following propositions:

(1) Congress may prohibit the movement across state lines of anything it pleases. ${ }^{19}$

(1a) In the exercise of this prohibitory power, Congress may describe the objects to be prohibited not only in terms of the intrinsic properties of the objects themselves, but also in terms of their relational properties, for example, the conditions under which they were brought into existence. ${ }^{20}$

(1b) Furthermore, in order to minimize the likelihood that there will be instances of movement across state lines by objects whose movement it prohibits, Congress may prohibit the creation of such objects or the maintenance of conditions necessary to their creation. ${ }^{21}$

(1c) The power to prohibit movement across state lines includes the movement of people as well as the movement of goods. ${ }^{22}$

(2) Congress may regulate local behavior with regard to any object that can be regarded as in transit on a journey that will involve

18. 505 U.S. 144 (1992).

19. See, e.g., United States v. Darby, 312 U.S. 100, 112-17 (1941).

20. See, e.g., 312 U.S. at 117-24.

21. For example, the employment of workers at substandard wages in the making of goods to be shipped across state lines. See 312 U.S. at 117-24.

22. See, e.g., Caminetti v. United States, 242 U.S. 470 (1917). This is as good a place as any to mention that of course there may be restrictions on the power(s) I describe, based on the First Amendment, the Fourteenth Amendment, and so on. Those restrictions do not concern us at present because our object is to summarize existing doctrine on an aspect of the distribution of powers between the federal government and the states. 
the crossing of state lines, even if the object is also transformed by processing at its local stops. ${ }^{23}$

(3) Congress may regulate behavior involving any object that has previously crossed a state line. ${ }^{24}$

(4) Congress may regulate any behavior that affects the quantity or identity of goods or people moving across state lines. ${ }^{25}$

(4a) This "affecting commerce" principle may be limited by the requirement that the behavior in question "substantially" or "significantly" affect the quantity or identity of goods or people moving across state lines; 26 but ... .

(4b) What must have a "substantial" or "significant" effect is not the individual instance of behavior, but the aggregate of all similar instances, ${ }^{27}$ so the limitation is of negligible effect, especially when we add that...

(4c) Congress may include in the aggregate not only instances of the type that individually have some effect on commerce, however slight, but also other instances that it is too difficult or inconvenient to distinguish from the foregoing, even if the additional instances on their own have no effect on commerce whatsoever. ${ }^{28}$

(5) Congress may regulate any aspect of the business, or anything that impinges on any aspect of the business, of instrumentalities of transportation or communication across state lines, including links in interstate transportation or communication networks that operate entirely within a single state. ${ }^{29}$

There is a great deal of overlap, both obvious and not-soobvious, in the propositions just enumerated, but that need not worry us. I am canvassing the standard jumping-off points for contemporary argument about the commerce power, not proposing a minimal axiom set. What is important to notice is that none of the propositions adverts to the question whether there is any reason

23. This somewhat obscure proposition reflects the obscurity of the "current of commerce" doctrine it represents. See, e.g., Swift \& Co. v. United States, 196 U.S. 375, 398-400 (1905).

24. See Scarborough v. United States, 431 U.S. 563 (1973) (semble); United States v. Bass, 404 U.S. 336 (1971) (semble); Daniel v. Paul, 395 U.S. 298 (1969) (semble); Katzenbach v. McClung, 379 U.S. 294 (1964) (semble).

25. See McClung, 379 U.S. at 294.

26. See Hodel v. Virginia Surface Mining \& Reclamation Assn., 452 U.S. 264, 276-80, 311 (1981) (Rehnquist, J., concurring).

27. See Wickard v. Filbum, 317 U.S. 111 (1942).

28. See Perez v. United States, 402 U.S. 146, 154 (1971) (semble); Mulford v. Smith, 307 U.S. 38, 47 (1939).

29. See Houston, E. \& W. Tex. Ry. v. United States (The Shreveport Rate Case), 234 U.S. 342 (1914); The Daniel Ball, 77 U.S. (10 Wall.) 557 (1870). 
why the regulation under consideration should come from the federal government. None of the propositions, that is to say, reflects any explicit concern with what might be the point of giving the federal government the power to "regulate commerce among the several states." To be sure, most of the laws and programs that have been justified by reference to these propositions are justified on my view as well. In most cases, there is some identifiable reason why the laws in question should come from the federal government. Still, every one of the propositions, as stated, can justify regulation that need not or should not emanate from the federal government. The propositions are all overbroad.

What is worse, from 1937 to 1995 they have been applied ever more formalistically. Current Commerce Clause doctrine is often praised as pragmatic. In the early years of the post-1937 period, when the Court made some passing attempts to explain why federal power needed to be broader than the formalism of Carter Coal ${ }^{30}$ allowed, such praise may have made sense. But the foundations of a new formalism were being laid even in United States $v$. Darby; ${ }^{31}$ and what now passes for Commerce Clause argument in Katzenbach v. McClung, ${ }^{32}$ and Daniel v. Paul, ${ }^{33}$ and by implication in United States v. Bass ${ }^{34}$ and United States v. Scarborough, ${ }^{35}$ is no more than a fetishism of state-line crossings. Current doctrine (preLopez) allows one to justify federal regulation by pointing to any connection between the activity regulated, whether in the particular instance or in the expansive aggregate, and some crossing of a state line by something or someone, sometime, somewhere.

This is not pragmatism; it is a new formalism. The essence of formalism in legal interpretation is paying no attention to the purpose embodied in the text one is interpreting. Our present Commerce Clause doctrine is not the same formalism as that of Carter Coal, but it is formalist through and through. It is "pragmatic" only in the sense that it can always serve the goal of justifying federal power. ${ }^{36}$

30. Carter v. Carter Coal Co., 298 U.S. 238 (1936).

31. 312 U.S. 100 (1941); see infra text accompanying notes 112-15.

32. 379 U.S. 294 (1964); see infra section III.B.3.

33. 395 U.S. 298 (1969).

34. 404 U.S. 336 (1971).

35. 431 U.S. 563 (1977).

36. Some degree of formalism - some resistance to starting afresh from a consideration of purpose on every occasion for interpretation - is necessary if we are to have anything that can be called positive law at all. See generally Frederick Schauer, Formalism, 97 Y ALE L.J. 509 (1988). But current Commerce Clause thinking has too thoroughly submerged the question of what the commerce power is for. 


\section{B. The Opinions in United States v. Lopez}

If we turn now to Lopez, we find that for the most part the majority and the dissenters talk past one another. The reason, I suggest, is that none of them is discussing the right question whether there is any reason why gun possession in school zones is better regulated by the federal government than by the states. Justice Breyer argues very convincingly in dissent that standard Commerce Clause doctrine justifies federal regulation of gun possession in school zones. ${ }^{37}$ That Katzenbach v. McClung, ${ }^{38}$ Daniel v. Paul, ${ }^{39}$ Perez $v$. United States, ${ }^{40}$ and Wickard $v$. Filburn, ${ }^{41}$ as they are conventionally understood, justify the Gun-Free School Zones Act seems undeniable. The trouble is that these cases, as they are conventionally understood, can justify anything. If we think there ought still to be some limit to Congress's power, then we cannot rely on the current standard arguments. Justice Breyer, unwilling to assert an unlimited commerce power, intimates that family law is still beyond Congress's reach. ${ }^{42}$ But I am confident it would be as easy to document that broken or dysfunctional homes damage educational achievement as to show that guns in schools do. If so, Justice Breyer's argument for the Gun-Free School Zones Act applies in identical fashion to a federal family law. The Lopez majority take the idea of a limit more seriously; they hold that the limit has been transgressed. But they need to explain why the limit is here, and their attempts to do so are lame.

Insofar as Justice Rehnquist attempts to explain why the GunFree School Zones Act is beyond the pale, he relies on the fact that what is being directly regulated - the possession of a gun in a school zone - is not commercial behavior. ${ }^{43}$ Justice Rehnquist is right that the behavior in Lopez differs in this respect from the behavior in McClung, Perez, and Wickard. Justice Breyer argues against Justice Rehnquist that what was forbidden by the statute in McClung was race discrimination, and what was forbidden by the statute in Perez was threatening violence, neither of which is commercial activity. ${ }^{44}$ But what the statutes forbade was race discrimi-

37. See United States v. Lopez, 115 S. Ct. 1624, 1657-65 (1995) (Breyer, J., dissenting).

38. 379 U.S. 294 (1964).

39. 395 U.S. 298 (1969).

40. 402 U.S. 146 (1971).

41. 317 U.S. 111 (1942).

42. See United States v. Lopez, 115 S. Ct. 1624, 1661 (1995) (Breyer, J., dissenting).

43. See $115 \mathrm{~S}$. Ct. at $1630-31,1634$.

44. See 115 S. Ct. at 1664 (Breyer, J., dissenting). 
nation in the operation of a restaurant, and threatening violence in order to collect a debt, which are clearly commercial. As to Wickard, growing wheat on a farm is commercial behavior. Even if some of the wheat is destined for the farmer's own table, the growing of that wheat is normally indistinguishable from the growing of what will be sold or fed to livestock.

But even if the leading cases involve commercial behavior, they do not rely on Justice Rehnquist's commercial-noncommercial distinction. The Wickard Court had enough doubt about the commercial nature of the behavior so that it said it did not matter whether the behavior regulated was commercial or not, provided there was an effect on commerce. ${ }^{45}$ Similarly, there is nothing in the opinions in McClung or Perez to suggest that the Court would not have agreed with this claim in Wickard. The focus is on effects on commerce, not on the commercial nature of the behavior regulated. So Justice Rehnquist's suggestion, while not inconsistent with the existing cases, is a highly tendentious gloss on them. ${ }^{46}$

Furthermore, it is easy to think up cases in which Congress's power to regulate noncommercial local behavior under the Commerce Clause should be obvious. Surely Congress can regulate private sport-hunting of migratory birds or drunk driving on interstate highways or backyard incinerators if they are found to emit some airborne toxic chemical that is deposited hundreds of miles from the site of incineration. ${ }^{47}$ In sum, Justice Rehnquist is not only offering a gloss on existing doctrine, it is an unacceptable gloss. Commerce Clause doctrine needs to be rethought, but we can rethink it better than this.

Despite what I have said, it may seem that Justice Rehnquist's suggestion for improving on current Commerce Clause doctrine is an obvious and appropriate one. It is, after all the Commerce Clause we are construing - which gives Congress the power to "regulate commerce ... among the several states." One problem with this line of argument is that even if we are faithful to the spirit of the sixth Virginia Resolution and believe in genuine limits on federal power, we are forced to construe some clause in Article I,

45. See Wickard, 317 U.S. at 125, noted in Lopez, 115 S. Ct. at 1663-64 (Breyer, J., dissenting).

46. Ironically, the actual instance of gun possession in Lopez was commercially motivated. Lopez was being paid for acting as a courier and delivering the gun to somebody else. See Brief for the United States at 7, United States v. Lopez, 115 S. Ct. 1624 (1995) (No. 93. 1260).

47. I hope these cases seem obvious. My relevant arguments are infra in sections III.A.1 and III.B.4.c. 
Section 8 in a not fully literal way to fill up the gap between the enumeration of specific powers and the current needs of the national system. An expansive reading of the Commerce Clause is what we have mainly relied on to fill this gap.

Even Justice Rehnquist does not suggest reading the Commerce Clause literally. Justice Rehnquist is apparently prepared to allow regulation of local commercial behavior that substantially affects interstate commerce. But regulating "all commercial behavior, whether interstate or local, that affects interstate commerce," which Justice Rehnquist would allow, is not at all the same as "regulating interstate commerce" in any ordinary understanding of language. In everyday speech, "regulate" most naturally means something like "adopt rules directly stipulating the conduct of ...," which is obviously much narrower than "adopt rules stipulating the conduct of other activities which affect ...." Furthermore, once we have expanded the federal power beyond directly regulating interstate commerce to regulating what affects interstate commerce, the language of the Commerce Clause does not require or even suggest limiting the relevant sources of effects to commercial behavior. The force of the reference to "commerce" in the text is exhausted by the requirement that it must be commerce that is affected. In sum, we cannot get Justice Rehnquist's position from the text.

Justice Kennedy, interestingly, seems willing to go further than the Court has ever explicitly gone in allowing federal regulation of local commercial behavior. Appealing to stare decisis, he says we should not go back to an eighteenth-century understanding of commerce, nor even to those times when "congressional authority to regulate undoubted commercial activities was limited by a judicial determination that those matters had an insufficient connection to an interstate system." 48 The implication of this last claim is that so long as Congress is regulating commercial behavior, the Court need not consider effects on interstate commerce at all.

Justice Kennedy defends this seemingly unlimited grant of power to regulate even local commercial behavior by saying that "we have a single market and a unified purpose to build a stable national economy." 49 But for many commercial offerings - laundry services, for example - we do not have a single market. And if the crucial point is the "unified purpose to build a stable national economy," then why may not Congress regulate noncommercial be-

48. Lopez, 115 S. Ct. at 1637 (Kennedy, J., concurring).

49. 115 S. Ct. at 1637 (Kennedy, J., concurring). 
havior that threatens that purpose, such as guns in schools? We still have found no justification for distinguishing between commercial behavior that affects interstate commerce and noncommercial behavior that does the same.

Justice Kennedy makes the further suggestion that where it is noncommercial behavior that affects commerce, the Court must ask whether the regulation intrudes on an area of "traditional state concern," in which case the Court has "a particular duty to insure that the federal-state balance is not destroyed."50 This is no help. The Court made another attempt, not twenty years ago, to exploit the concept of areas of traditional state concern, ${ }^{51}$ and it gave up the attempt only nine years later because of the indeterminateness of that concept. ${ }^{52}$ On the one hand, every area might be said to be an area of traditional state concern until the federal government takes an interest in it; on the other hand, with regard to Lopez specifically, the federal government has long taken an interest in aspects of primary and secondary education and in regulating firearms. Finally, even if we accept for purposes of argument that there are recognizable areas of traditional state concern, in which the Court should be specially solicitous to protect a proper balance of federal and state power, that tells us nothing about how to identify the proper balance, or to know when it is destroyed. Justice Kennedy gives us little indication of how to answer what is, on his formulation, the central question.

Justice Kennedy observes in this part of his opinion that if the states decide criminal sanctions for guns in schools are desirable, "the reserved powers of the States are sufficient to enact those measures." 53 If we take this simply as the observation that the states have legal power to act in the area, then it obviously does not settle the issue of whether there is federal power as well. We no longer suppose that the spheres of state and federal power are mutually exclusive. But if Justice Kennedy is saying not only that the states have the legal power to act on this problem, but also that there is nothing in the situation to undercut their practical ability to deal with it independently, then he is addressing one aspect of the question whether there is any need for federal intervention (which is the right question) and concluding there is none (which, on the face of it, is the right answer).

50. 115 S. Ct. at 1640 (Kennedy, J., concurring).

51. See National League of Cities v. Usery, 426 U.S. 833 (1976).

52. See Garcia v. San Antonio Metro. Transit Auth., 469 U.S. 528 (1985).

53. Lopez, 115 S. Ct. at 1641 (Kennedy, J., concurring). 
Justice Kennedy points out also that there may be significant costs to federal intervention because some states may have chosen to try to eliminate guns from schools by methods the federal law will interfere with. ${ }^{54}$ The suggestion is plausible, and this is definitely a cost of intervention that Congress ought to take seriously. But in the end, the weighing of such costs is for Congress, if there is a case for federal intervention in the first place. Costs such as this do not determine whether there is the right sort of case for federal power. ${ }^{55}$ Insofar as Justice Kennedy can be read as saying there is not the right sort of case for federal power, I agree; his opinion, however, puts the spotlight in the wrong place and does not fully explain why not.

Both Justice Kennedy's opinion and Justice Rehnquist's also appear to leave in place an uncommonly silly bit of existing Commerce Clause doctrine, which would allow Congress to repass the Gun-Free School Zones Act unaltered, with a new asserted justification. Notice that just making the findings suggested in Justice Breyer's dissent, ${ }^{56}$ as Congress later did, ${ }^{57}$ does not make the statute constitutional under the majority opinions because it does not change the fact that gun possession is not a commercial activity. ${ }^{58}$ Congress needs to be a bit more devious. Consider first a "Hypothetical Gun-Free School Zones Act," making it a federal crime to possess in a school zone any gun that has moved in interstate commerce. Would this Act be constitutional? Neither Justice Rehnquist nor Justice Kennedy addresses this question directly, but there are passages in both opinions suggesting that this statute, because it relies on an appropriate "nexus" with commerce, would

54. See 115 S. Ct. at 1641-42 (Kennedy, J., concurring).

55. What does determine it, I shall discuss below. See infra Part III.

56. See 115 S. Ct. at 1658 (Breyer, J., dissenting).

57. See Violent Crime Control and Law Enforcement Act of 1994, Pub. L. No. 103-322, 108 Stat. 1796.

58. Of course, if we are interested in purely behavioral hypotheses, it seems quite possible that if Congress had made these findings the first time around, the Court would have come out differently. Some Justice in the majority, most likely Justice Kennedy or Justice O'Connor, might have reacted differently to the case if there had been evidence that Congress had given this bill serious thought. For that matter, if Congress had made these findings the first time around, the Fifth Circuit might not have had the nerve to strike down the law, see United States v. Lopez, 2 F.3d 1342 (5th Cir. 1993), affd., 115 S. Ct. 1624 (1995); if the Fifth Circuit had upheld the law, the Supreme Court might well not have granted certiorari. So, these findings might well have made a practical difference. It is true nonetheless that they are irrelevant under the theories the majority ended up putting forward in deciding the case as it came before them. 
pass muster.59 This legislative technique is of course wellestablished in the gun-control area. 60

Assuming then that the Hypothetical Gun-Free School Zones Act would be constitutional, suppose that Congress had offered in favor of the actual Gun-Free School Zones Act, which of course contains no reference to the gun's having moved in commerce, the following argument: "We could have passed the Hypothetical GunFree School Zones Act. But in fact virtually all guns in individuals' possession have moved in commerce. In order to avoid the inconvenience and complication and occasional difficulty of proving actual movement in commerce, we have simply forbidden the possession of all guns in school zones. So there." It seems to me this argument, though it may be disingenuous, ought to prevail. Congress is entitled to some margin of overinclusiveness for purposes of insuring adequate enforceability, ${ }^{61}$ and the Gun-Free School Zones Act, accompanied by these findings, is within the margin the Court should allow around the Hypothetical Gun-Free School Zones Act.

We see that the majority's reasoning does not definitively establish the unconstitutionality of the Gun-Free School Zones Act. More to the real point, the majority's reasoning leaves it open to Congress to justify the Act by an argument that is thoroughly unsatisfying because it still does not suggest any adequate reason for federal involvement. The source of the difficulty is not the "margin of overinclusiveness" reasoning by which we justify the actual Act given the constitutionality of the Hypothetical Act. The source of the difficulty is the idea that the Hypothetical Act is acceptable just because it limits itself to guns that have moved in commerce. To be sure, the fact that many guns move in commerce is an important element in a plausible argument that can be made for extensive fed-

59. See Lopez, $115 \mathrm{~S} . \mathrm{Ct}$. at 1631 (Rehnquist, J.) (holding that the statute lacked a jurisdictional element ensuring that the firearm possession affected interstate commerce); $115 \mathrm{~S}$. Ct. at 1640 (Kennedy, J., concurring) (observing that "neither the purposes nor the design of the statute have an evidential commercial nexus").

60. See, e.g., Federal Gun Control Act of 1968, Pub. L. No. 90-618, 82 Stat. 1213 (codified as amended at 18 U.S.C. $\$ \$ 922(\mathrm{~g}),(\mathrm{h}),(\mathrm{j})(1994))$.

61. See, e.g., Perez v. United States, 402 U.S. 146, 154-55 (1971) (semble); Mulford v. Smith, 307 U.S. 38, 47 (1939). Tot v. United States, 319 U.S. 463 (1943), does not forbid the move from the Hypothetical Gun-Free School Zones Act to the actual Act. The statutory presumption overturned in Tot involved presuming both (a) that the gun involved in the case had been received by the defendant in an interstate transaction, and (b) that this transaction had occurred after the (then recent) effective date of the statute. Obviously, neither presumption is at all well-grounded. In contrast, the presumption, if that is how we think of it, that any gun in an individual's possession has at some time crossed a state line, I assume is very well-grounded indeed. 
eral power over guns. ${ }^{62}$ But a statutory requirement that a particular gun have moved in commerce does not suffice by itself, under a sensible Commerce Clause theory, to justify a prohibition on possession of that gun.

I have said that I am inclined to think the result in Lopez is correct - which is not to say there is nothing Congress could assert in justification that would change my mind. It would be premature to explain in detail how my approach deals with Lopez, but the central point is clear enough. There is nothing in the background of the statute to suggest that states are less capable of dealing with the problem of guns in schools than the federal government; ${ }^{63}$ nor is there anything to suggest the states are inadequately motivated to do so. ${ }^{64}$ In other words, there is no reason to think the federal government could or would do a better job of dealing with this problem than the states. ${ }^{65}$ If Congress had suggested any reason why federal intervention was specially likely to help, the case might have been different. But I think the Court was justified in not treating the mere fact of the legislation as a finding by Congress that they had something to contribute, to which the Court ought to defer.

I do not mean to suggest by this defense of Lopez that the present extensive federal regulation of guns is all unconstitutional. Guns are small, portable, concealable, dangerous, and often used in crime. There is evidence of a significant interstate traffic in handguns specifically intended for criminal use. ${ }^{66}$ We may assume states have legal power to regulate the purchase and possession of guns, ${ }^{67}$ but, as a practical matter, the states cannot police their borders with perfect efficiency. The federal government, with nationwide terri-

62. See infra notes $66-67$ and accompanying text.

63. The only interesting suggestion in the legislative hearing is the claim by various witnesses that federal criminalization would send a signal to society at large and to potential violators of the statute that Congress and the nation are committed to doing something about the problem - a wonderfully 1990s version of general deterrence. See generally Gun-Free School Zones Act of 1990: Hearings on H.R. 3757 Before the Subcomm. on Crime of the House Comm. on the Judiciary, 101st Cong., 2d Sess. (1990). For some related speculation about the role of public perceptions in justifying federal action, see infra text accompanying notes 166-67.

64. The second point is important if we regard guns in schools as threatening a "general interest of the union," which would considerably expand Congress's prerogative. See infra section III.A.2.

65. As I have noted, this argument is suggested in Justice Kennedy's opinion. See United States v. Lopez, 115 S. Ct. 1624, 1641 (1995).

66. See generally Franklin E. Zimring, Firearms and Federal Law: The Gun Control Act of 1968, 4 J. LeGAL STUd. 133 (1975).

67. See Presser v. Illinois, 116 U.S. 252 (1886) (refusing to incorporate the Second Amendment against the states). More sophisticated current arguments about whether this is good law, we need not now consider. 
torial jurisdiction, undoubtedly has significant advantages in enforcing regulations on the movement of guns. Such considerations go far to justify existing regulations focusing mainly on dealers and out-of-state purchasers, felons, incompetents, juveniles, and the like, and on weapons with no apparent noncriminal use in civilian life. They might suffice to justify broader regulation still. But complete prohibition of gun possession in a specified sort of locale under state jurisdiction does not seem like a response to the sort of concerns about uncontrolled movement of guns that suggest state incapacity.

My defense of Lopez may seem rather half-hearted. And so it is. My primary interest is not in getting the federal government out of school zones, but in changing the way we think about whether it should be there. I shall return to Lopez a bit further on, when I consider a possible justification of the Gun-Free School Zones Act that exploits the same facts Justice Breyer relies on in his dissent, but in a different theoretical context. 68 The revised justification will depend on the idea that economic productivity is a "general interest of the union." Once again I shall suggest that the conditions for congressional intervention are not met - but with no more zeal for the particular conclusion in the particular case than I show here.

\section{How To Think About the Commerce Power}

At last we are ready to take up the central question: What sorts of considerations should be held to justify federal intervention? Recalling the Virginia Resolution, I propose to consider first arguments based on "general interests of the Union" and then to look at "cases ... to which the states are separately incompetent." 69 I shall not consider separately cases "in which the harmony of the United States may be interrupted" by state legislation; for the most part, the idea here is clear enough, and I shall comment on a few examples in passing in the course of our other discussions. I do not mean to suggest that we should treat the Resolution as a canonical constitutional text, which it is not. But the specific clauses do suggest the main modes of arguing for the special necessity or desirability of federal power. ${ }^{70}$

68. See infra section III.A.2.

69. NOTEs of Debates, supra note 4, at 298-304, 380.

70. The Framers themselves were unclear about the precise reach and interrelations of the various clauses. On July 16 , Pierce Butler objected to the vagueness of the idea of the states' incompetence and asked for explanation. He received none, and a sympathetic motion by John Rutledge to commit the Resolution for greater specification was defeated on an even division. See id. at 298-99. On July 17, when the Resolution took its final form, the 


\section{A. "General Interests of the Union"}

By "general interest of the union" I mean, and I suggest the Framers meant, an interest belonging to the nation as a whole, as a nation. Obvious examples, drawn from the sphere of foreign affairs, would be national security and access to international trading opportunities on favorable terms. "General interests of the union" do not include interests that many, or even all, states just happen to have in common. Nor do they include just anything Congress thinks would be desirable for the people of the United States as a whole. So, for example, reducing violence in schools is not on the face of it a "general interest of the union" even if it is desired by every state and by Congress as well.

If this seems somewhat artificial, it is nonetheless a perfectly plausible construction of the phrase "general interests of the union," and some such construction is necessary if we are to avoid creating an unlimited federal power under this rubric. When the language about "general interests" was proposed as an amendment to the Virginia Resolution by Gunning Bedford, Edmund Randolph, the original author of the Resolution, objected that the language was too broad. Bedford prevailed, perhaps partly on the strength of his assertion that the language actually added nothing because the states were incompetent to legislate for the general interests. ${ }^{71}$ In any event, it is clear that the reference to general interests was not intended to displace the idea of a limited federal government.

\section{Transportation and the Error of the "Toll-Gate" Power}

We can begin the discussion of specific "general interests" where our Commerce Clause jurisprudence began in Gibbons v. $O g d e n^{72}$ - with transportation and communication. The existence of efficient networks for interstate transportation and communication is one of the "general interests of the union," perhaps the most

convention defeated a motion by Roger Sherman to limit the national legislature to cases that "concern the common interests of the union." Id. at 303. The clause about federal power to legislate for the "general interests of the union," which had not been in Randolph's original version of the Resolution, was now added, on the motion of Gunning Bedford. Id. Randolph himself objected that the addition was overbroad. See id. Bedford retorted that it actually added nothing because no state was separately competent to legislate for the general interests of the union. See id. at 304. With no further clarification of this part of the Resolution, but only a pause to remove from Randolph's original a power of the federal legislature to negative laws of the states, the Resolution was adopted by a vote of eight states to two. See id. at 304.

71. See supra note 70 .

72. 22 U.S. (9 Wheat.) 1 (1824). 
obvious and the preeminent internal "general interest of the union." Efficient interstate transportation and communication is essential to our being a union. Without effective means for the interchange of ideas, people, and goods, the people of the various states could hardly have come to consider themselves a single nation. Free interchange continues to be essential for a feeling of national solidarity.

Of course, what is required is relative to the standards of the day. In 1824, when Gibbons v. Ogden was decided, it was essential to our being a union that steamboat traffic be unimpeded - or at least it was open to Congress to think so. It was not necessary that there be an efficient system of transportation by air. On the other hand, we could not be a nation in the modern world with no systems of transport and communication beyond the horse, sailing ships, and steamboats.

Not only is there a "general interest" in transportation and communication, there are reasons why this interest would not be wellserved by leaving transportation and communication to exclusive state regulation. Standards for the safety and financial health of instrumentalities that operate physically in many states are likely to require harmonized, and therefore central, regulation. ${ }^{73}$ In addition, if the states are left without federal supervision, they may disrupt "the harmony of the United States" by protectionist legislation like the New York steamboat monopoly overturned in Gibbons. Protectionism aside, individual states may just want to shirk in various ways the burden of allowing transshipment of goods and people across their territories, which they undertook when they joined the union. ${ }^{74}$ On the basis of these considerations, Congress may properly make whatever regulations it sees fit for the existence, safety,

73. I say "harmonized, and therefore central," regulation. The die-hard antifederalist might suggest that harmonization can be achieved just by interstate cooperation. But cooperation is often hard to achieve. What the antifederalist overlooks in her argument is that the federal government was created as one mechanism for, or perhaps better as a stand-in for, interstate cooperation. It was a dangerous mechanism because the states as such gave up all operating control over the central government in the areas of its competence. But experience had shown that in some areas the need for this sort of mechanism for harmonization of laws and policies was great enough to justify the danger. What we now have to do, of course, is to answer the question, "Which areas?" But no area can be excluded from federal competence by the bare claim that state cooperation could in principle deal with the problems. That is true everywhere, even in foreign relations.

74. That the state undertook this burden is the strong implication of, for example, Duckworth v. Arkansas, 314 U.S. 390 (1941). For examples of cases where the states appeared to be trying to shirk the burden, see Kassell v. Consolidated Freightways Corp., 450 U.S. 662 (1981); and Raymond Motor Transport, Inc. v. Rice, 434 U.S. 429 (1978). 
efficiency, and accessibility of instrumentalities of interstate transportation and communication.

As I have noted, our Commerce Clause jurisprudence began with Gibbons v. Ogden, and Gibbons is commonly read as a prescient anticipation of the essentially unlimited commerce power we now recognize..$^{75}$ But, as Justice Thomas points out, to read Gibbons thus is to find in it more than is there. ${ }^{76}$ It is worth remembering that as constitutional cases go, Gibbons was very straightforward, involving both the national interest in unfettered transportation and the sort of state economic protectionism that the Framers had feared as a threat to the harmony of the United States. ${ }^{77}$

When Marshall says in Gibbons that the commerce power does not extend to concerns "completely within a particular state, which do not affect other states," 78 he is stating a necessary condition for the relevance of the commerce power, but he need not be taken as stating a sufficient condition also, saying that any behavior that affects other states is subject to federal regulation. ${ }^{79}$ To be sure, Marshall also implies that the federal power extends to behavior that "concerns more states than one," 80 but "concerns" is a very unspecific term. It is at least as plausible to read Marshall as referring to behavior that has some direct connection with more than one state, as it is to read him as asserting federal power over all local behavior that has any out-of-state effect. ${ }^{81}$

When Marshall says that " $[\mathrm{t}]$ he genius and character of the whole government seem to be, that its action is to be applied to all the external concerns of the nation, and to those internal concerns which affect the states generally," 82 he is echoing the thought and language of the Virginia Resolution. The very orotundity of the paragraph from which these quotes are taken, the piling up of similar, mostly vague, phrases, argues against looking here for anything much more specific than the general idea of the Resolution. To be

75. See, e.g., Robert L. Stern, The Commerce Clause and the National Economy, 19331946, 59 HARV. L. REV. 645, 648 (1946).

76. United States v. Lopez, 115 S. Ct. 1624, 1646-48 (1995) (Thomas, J., concurring).

77. See Donald Regan, The Supreme Court and State Protectionism: Making Sense of the Dormant Commerce Clause, 84 Mich. L. REv. 1091, 1114 (1986).

78. Gibbons v. Ogden, 22 U.S. (9 Wheat.) 1,195 (1824).

79. See Lopez, 115 S. Ct. at 1646-49 (Thomas, J., concurring).

80. Gibbons, 22 U.S. (9 Wheat.) at 194.

81. I shall argue in greater detail later against current expansive readings of the "affecting commerce" idea, see especially infra section III.B.3.

82. Gibbons, 22 U.S. ( 9 Wheat.) at 195. 
sure, if we resist the temptation to overread these phrases in Marshall's opinion, we are left with no complete specification of the extent of the commerce power. But we should not expect a complete specification in a first, easy case. ${ }^{83}$

Many later cases have also involved the special federal interest in transportation and communication. The Shreveport Rate Case, ${ }^{84}$ though it is often quoted from in support of the very general "affecting commerce" doctrine, was a case about regulation of the instrumentalities of interstate transportation. Like Gibbons, it also involved the issue of interstate discrimination. Between Gibbons and the Shreveport Rate Case, the Supreme Court decided The Daniel Ball, ${ }^{85}$ upholding the application of federal safety regulations to a steamship that navigated entirely within the state of Michigan because it carried goods that were bound on interstate journeys. This seems to me to make perfect sense. The system is one of national transportation. All of the elements of the system are operating at any given time within the confines of some particular state. ${ }^{86}$ The power to regulate some particular element should not depend on whether that element itself ever moves across state lines or not.

The ease with which I accept The Daniel Ball illustrates an aspect of my general approach to these questions. Once we have identified a plausible kind of argument for federal legislation, I am prepared to interpret it liberally and to defer to Congress's decision that the argument really does justify federal intervention in a somewhat marginal case. It is the foundations of our Commerce Clause thinking that I want to revise, not the assumption of a wide latitude for Congress in practice.

As a further example of my liberality, I am inclined to regard Garcia v. SAMTA 87 as a modern analogue of The Daniel Ball and to regard Garcia as right on its facts because even the municipal transportation system of San Antonio is part of the national system. The Court was wrong to rely on the more general "affecting commerce" rationale, for reasons I shall explain when I discuss National

83. The later comments about the power being "plenary" as to its specified objects and subject only to political checks on its exercise, Gibbons, 22 U.S. (9 Wheat.) at 197, do not help us define the extent of the power. They presuppose that the extent of the power has already been determined.

84. Houston, E. \& W. Tex. Ry. v. United States, 234 U.S. 342 (1914).

85. The Daniel Ball, 77 U.S. (10 Wall.) 557 (1870).

86. Cf. Gibbons, 22 U.S. (9 Wheat.) at 195.

87. Garcia v. San Antonio Metro. Transit Auth., 469 U.S. 528 (1985). 
League of Cities v. Usery88 and Katzenbach v. McClung.89 As I have said, this suggestion about Garcia is an illustration of how far I am willing to go if we start from what seem to me the right sort of premises. I do not mean to make this application a test case for my general view.

Another decision that can be justified by reference to the national interest in the transportation system is Heart of Atlanta Motel. ${ }^{90}$ The motel never moved from its location on Courtland Street, no more than the Daniel Ball ever left Michigan waters, but by advertising vigorously for interstate travelers, and serving many of them, the Heart of Atlanta Motel made itself part of the interstate system for the movement of people. What Heart of Atlanta illustrates is that Congress may not only legislate for the existence, safety, and efficiency of the instrumentalities of interstate transportation; it may also guarantee access and decent treatment of patrons. ${ }^{91}$

It may seem at this point that my suggestions for revising Commerce Clause thinking are rather anticlimactic. Is my view about the importance of the transportation and communication system so different from the fifth proposition in my summary above of existing doctrine? ${ }^{92}$ The fact is that I have begun at the point where the superficial similarities between my approach and existing doctrine are the greatest. But even with regard to the regulation of transportation and communication, there is at least one extremely important difference between my approach and existing doctrine. I have said that the federal government may guarantee access to the instrumentalities of transport and communication. Standard analysis, in contrast, assumes that Congress may guarantee or deny access as it chooses, provided, of course, that it violates no principle protecting individual rights. This seems to me mistaken. Nothing in the idea that there is a national interest in the availability of safe and efficient systems for transportation and communication entails

88. 426 U.S. 833 (1976).

89. 379 U.S. 294 (1964).

90. Heart of Atlanta Motel v. United States, 379 U.S. 241 (1964).

91. Heart of Atlanta can also be justified, of course, by reference to the Reconstruction Amendments. It is important that this is so because I shall argue below that Katzenbach v. McClung cannot be justified on Commerce Clause grounds without considerable strain, and must rely on the pure antidiscrimination argument. To mention just the one point about McClung which is germane to the present context, Ollie's Barbecue was not an element in the interstate transportation system in the way the Heart of Atlanta Motel was.

92. See supra text accompanying note 29 . 
that Congress should have carte blanche to close those systems to anything it chooses.

Consider, for example, lottery tickets. Imagine a background very different from that of Champion $v$. Ames. ${ }^{93}$ Imagine that none of the states disapproves of lotteries, but that a small antilottery clique among the influential members of Congress does believe that lotteries are immoral and corrupting. This clique pushes through a largely indifferent Congress a law forbidding the transportation of lottery tickets across state lines - transportation that will necessarily involve some instrumentality of interstate transportation, even if it be only the roads. I would say that this law is beyond Congress's power. There is simply no reason why we need the federal government as opposed to the states to make a primary decision about the propriety or desirability of lotteries. Suppression of lotteries is not a "general interest of the union" for which Congress has a primary policymaking role.

I have not said that Champion v. Ames was wrong in its result. At the time of Champion, most if not all of the states had decided that lotteries were immoral and had legislated against them, ${ }^{94}$ and there may have been good reason why a federal prohibition on the interstate transportation of lottery tickets was a necessary, or at least a very useful, aid to the states in the enforcement of their own choices about lotteries. Lottery tickets are small, portable, concealable, and in some views dangerous - like guns. Stamping out lotteries may have been something the states were individually incompetent to do, practically speaking. As I said in connection with guns, there are advantages to a government with nationwide territorial jurisdiction.

But there is all the difference in the world between Congress's legislating against lotteries just because it disapproves of them and Congress's legislating against lotteries to help the states give effect to their own judgments of disapproval. The former is not something we need the national government for; the latter perhaps is. To be sure, once a number of states disapprove of lotteries, and there is some positive reason of the sort I have hypothesized for Congress to consider acting in the area, it may be impossible to insist, and undesirable to try to insist, that Congress form no judgment of its own about just how bad lotteries are. The states may not have uniform views, and Congress must in any case decide what

93. 188 U.S. 321 (1903).

94. See 188 U.S. at 357. 
measures are worth using in support of the states' policies. That is why I qualified my statement above by saying there was no need for Congress to make a primary decision about the desirability of lotteries. Still, the qualification does not undermine the basic point. Lotteries implicate no "general interest of the Union," no interest of the national union as such. Accordingly, deciding whether lotteries should be permitted is, in the first instance, a matter for the states. If the states are incompetent to make their choices effective, there may be good reason for Congress to suppress the interstate movement of lottery tickets; the reason, however, cannot be simply that Congress disapproves. When the basic justification for congressional power is state incompetence - a justification we shall examine in more detail presently - Congress should act only to further the policies of the states, or at least some of them.

Current Commerce Clause thinking grants to Congress a completely general "toll-gate" power to restrict movement across state lines and allows Congress to use this means to promote any policy it chooses. To my mind, that is a mistake.

The reader may be thinking at this point that the power to prohibit movement of specified objects across state lines is squarely within the literal meaning of the Commerce Clause. Does not the power to "regulate commerce among the states" clearly include the power to prohibit commerce?

If an unrestricted toll-gate power were undeniably within the literal meaning of the Commerce Clause, this would be a case in which the enumeration of powers the Committee of Detail supplied went beyond the spirit of the Virginia Resolution. That should give us pause. As it happens, I do not think the literal meaning clearly includes this power. One meaning of "regulate" is "smooth out, make ruly." If that is what "regulate" means, then it is far from undeniable that absolutely and permanently prohibiting a type of commerce that is not uncontroversially destructive is a mode of "regulating" it.95

95. Notice that this suggestion about the meaning of "regulate" can coexist perfectly with my earlier suggestion that "regulate" most naturally means "adopt rules directly stipulating the conduct of ...." The earlier point concerned what "regulate" suggests about the direct incidence of the rules adopted, while the present point concerns what "regulate" suggests about the content and purpose of the rules.

In response to my present claim about the meaning of "regulate," it could be pointed out that Congress is also given the power to "regulate" commerce with foreign nations; and it is given that power by the identical occurrence of the word "regulate," which appears only once in the Clause. But surely the meaning of "regulate" as it applies to foreign trade includes flat-out prohibition - why else would the Constitution explicitly limit the power of Congress to prohibit the importation of slaves before 1808 , in Article I, § 9 ? 
Notice I have not said Congress may never deny access to the means of transportation or communication without prior state decisions. Diseased cattle, inadequately secured toxic chemicals or high explosives, rowdy passengers, firearms or weapons on airplanes all these Congress may exclude in its own pursuit of the safety and convenience of the systems themselves. But lottery tickets, or for that matter goods manufactured under substandard labor conditions, do not pose the same sort of threat to the trucks, trains, ships, or planes carrying them.

Notice also I have not given as the reason why Congress should not make a primary decision about lotteries that this is a "moral" question as opposed to an "economic" one. The distinction itself is doubtful in the present context. All decisions about what the law should be are moral decisions in part. To which side of the "moraleconomic" divide could we assign the question whether to have a minimum wage, or progressive taxation, or endangered species protection? Even with regard to lotteries, many people who regard them as immoral think they are so only because they involve commercial exploitation of an inclination for gambling that is usually quite harmless when pursued by individuals in their own small groups. To be sure, there are contexts in which there is a useful distinction to be made between "moral" and "economic" questions, including perhaps even a few specialized legal contexts, 96 but the present context is not one of them. "Economic" decisions are quite as much for the states in the first instance as "moral" decisions. All governmental decisions are for the states unless there is a particular reason for federal intervention. ${ }^{97}$ It may be that reasons for federal

For myself, I have no compunction whatever about arguing that "regulate" has a different most natural meaning as applied to foreign and to interstate commerce, given that the situations of the union and the individual states are quite different in these two arenas. The Framers used the word "regulate" only once in this clause, but that was a consequence of linguistic compression. They were doing two quite different things. This is not mere speculation. We know that the main point of giving Congress the power to regulate foreign commerce was so the nation could present a unified front in international trade negotiations, with the federal government setting the national policy. See THE FEDERALIST No. 11 (Alexander Hamilton). We know also that the main reason for giving Congress the power to regulate interstate commerce was to allow Congress to override state protectionist measures. See Albert S. Abel, The Commerce Clause in the Constitutional Convention and in Contemporary Comment, 25 MrNN. L. REv. 432, 481-94 (1941). We have expanded the interstate Commerce Clause far beyond that purpose, but the observation is still enough, I think, to defend my "two meanings" thesis against the objection that it is pure ad hoc-ery. We must never forget that it is a constitution we are expounding.

96. For example, distinguishing between beliefs that entitle one to conscientious objector status and beliefs that do not. $C f$. Welsh v. United States, 398 U.S. 333 (1970) (holding that a firmly held moral belief entitles one to conscientious objector status).

97. Specific constitutional grants of power to the federal government and specific denials of power to the states, insofar as these grants and denials seem clear and not in need of 
intervention are more often present in connection with issues involving a significant economic dimension. But this generalization is a statistical summary, not a principle for deciding cases.

\section{Economic Productivity and Lopez}

Let us turn now to another "general interest of the union," which is suggested by the dissents in Lopez. Is there not a "general interest" in national economic development and productivity? Is not any serious threat to our educational system, such as guns in the schools, a threat to that general interest? The argument embodied in these rhetorical questions depends on precisely the facts recited in the Lopez dissents. But it puts them in a different theoretical context. We shall see that the difference matters.

I think we can hardly deny that in the modern world, there is a general interest in economic development and productivity. The crudest argument, but no less important for that, is that economic power underwrites military power, which is important for national defense and for not-so-defensive pursuit of other national interests in the international sphere. More subtly, in the late-twentieth century, international stature and influence depend more and more on economic power, even aside from military considerations - witness the rising diplomatic stock of Germany and Japan. Also, our own national identity over the past century has been peculiarly dependent on economic power. For decades we were both the world's leading military power, or one of two, and the issuer of the world's principal reserve currency. If our national identity is fraying a bit, the loss of economic dominance in the world is among the reasons.

Granting that there is a general interest in economic productivity, an effective educational system is important to that interest. But we should also note in passing that an educated citizenry is arguably itself, directly, a general interest of the union. The mobility of our population means that every state has an interest in how other states are preparing their young citizens for life in a modern industrial democracy. Also, so long as there are important general interests to be pursued through a national political process, there is a general interest of the union in an educated and aware national citizenry.

Even this brief discussion of economic productivity and education as general interests of the union makes it clear that Edmund

interpretation, may be regarded as embodying the Framers' conclusive decisions that such particular reasons exist. 
Randolph had good reason to worry that the "general interests" idea would subvert all limits on the federal power. Is it possible to limit arguments based on such general interests as these? And incidentally, where does all this leave the Gun-Free School Zones Act?

The first and most important point, which I think would certainly have a restraining effect on a conscientious legislator, is to notice that what we should be concerned with are fundamental threats to the viability or productivity of the economy as a whole. A failing educational system is such a threat. Indeed, our educational system may be in such a state that, quite aside from violence in schools, Congress would be justified in extensive regulation if it had any reason to believe that its intervention would improve things. But the idea that Congress can act against serious threats to the productivity of the economy in general - or even against threats to any essential sector - is much narrower than the current idea that Congress can regulate whatever "affects commerce." The mere fact that some local law or practice reduces the quantity of goods moving across state lines, for example, does not mean it is a threat to our national economic viability that Congress can act against. ${ }^{98}$

Limiting Congress's concern under this rubric to threats to the general health of the economy, and arguably to moderately serious threats, follows from the basic idea of what counts as a "general interest of the union." I would suggest a further limitation, which does not follow in quite the same way, but that is calculated to guarantee that Congress acts only where there is some special need. Even with regard to some threats to a general interest of the union, the states may be as well situated to deal with the threat as Congress, and they may be adequately motivated to deal with it. Guns in schools are a possible example. Assuming guns in schools are a threat to our national productivity, they are a threat that operates locally in the first instance. It is far from clear that Congress has any advantage over the states in dealing with this problem defined in this way. Even if Congress has no advantage in competence, it would still have adequate reason to intervene if the states were motivated to ignore or subvert the general interest. But that also seems implausible. To be sure, the mobility of our citizenry means that some of the benefits from a state's educational system accrue to other states. But I find it hard to believe that any state is underinvesting in trying to stop guns in schools for that reason. Surely

98. For further discussion of the "affecting commerce" idea, see infra section III.B.3. 
the real difficulty at the moment is that the problem is relatively new, and no government knows what best to do about it.

In sum, we have two ideas that limit the reach of the argument from economic productivity as a general interest. One of these ideas, that not every law "affecting commerce" is connected with a threat to our productivity, is irrelevant to justifying the result in Lopez because a serious threat to educational quality is a threat to our productivity. The other idea, that Congress should act to protect general interests only where the states are either incompetent or inadequately or perversely motivated, does apparently justify the result in Lopez, given Congress's failure to lend any plausibility at all to the notion that it had a special contribution to make.

Lopez is not an ideal case for illustrating or testing my theory. That is because my argument for Lopez and against the Gun-Free School Zones Act depends on an idea - the idea that even in pursuing general interests of the union, Congress may not act unless the states are either less competent or inadequately or perversely motivated - to which I am relatively weakly committed as compared to other parts of my theory. By my own hypothesis, this is not a case where Congress and the states have different goais. If they did, and Congress's goal was the promotion of a general interest of the union, Congress would have good reason to override the state. The sort of case that troubles me most is a case in which there is no general interest and Congress overrides some state's choice without adequate reason based in the structure of interaction between the states. It seems a bit paradoxical to say that where there is a general interest, Congress may act against a state's choice if the state has chosen against the general interest but Congress still may not act in support of the states' choice for the general interest absent some showing of state incompetence. Paradoxical or not, for the moment I am prepared to defend the result in Lopez on these grounds. I note that Justice Kennedy's point about Congress's law possibly interfering with better state approaches is a supplementary supporting consideration in this context. 99 But for me, I repeat, Lopez is not the central problem.

\section{The Environment}

Are there other domestic general interests of the union we have not yet discussed? There is a domestic interest in national security and integrity that corresponds to the international version of that

99. See United States v. Lopez, 115 S. Ct. 1624, 1641 (1995) (Kennedy, J., concurring). 
interest. From a legal point of view, what else justified Congress in fighting a war to prevent the Confederate States from seceding? But are there any other, distinctive internal "general interests"?

It is not necessary to my project to offer a definitive answer. One candidate I find interesting to think about is a general interest in our nation's natural environment and resources. ${ }^{100}$ Of course the states have interests, severally, in the preservation, conservation, and exploitation of the parts of our natural heritage that lie within their boundaries; we shall see that extensive federal environmental legislation can be justified by the difficulty the states face, acting separately, in protecting those several interests. ${ }^{101}$ But it seems to me a case could also be made that there is a relationship between the nation as a whole and the natural heritage of the nation considered as a whole, that gives rise to a general interest in our environment and resources that is not just the sum of the interests of the states. Most of our territory, it should be remembered, belonged to the United States before it belonged to the states that now occupy it. This is true even with regard to much of the territory between the Appalachians and the Mississippi, where claims by various original states were ceded to the United States as a condition of securing Maryland's ratification of the Articles of Confederation. ${ }^{102}$ In the mid-nineteenth century, it was seen as the "manifest destiny" of the United States to extend its dominion to the Pacific"103 - it was not the destiny of Tennesseans or Pennsylvanians, but of Americans, to rule the continent. All of this may ground a "general interest of the union" in the treatment of our natural heritage, which might in some cases - say, the protection of nonmigratory wildlife, or certain decisions either preventing or insisting on the exploitation of natural resources against the wishes of the state in which they are located - justify federal regulation for which no other argument is available. I am content to leave this as speculation; how important it might be cannot even be estimated until we have considered the possible scope of other sorts of argument.

100. Let me emphasize that to suggest something is a "general interest" is not to say anything about how much weight it deserves when balanced against other interests, general or particular. The issue here is about what entity is the subject of the interest, not how vigorously to pursue it.

101. See infra section III.B.4.c.

102. See Bernard Bailyn et. al., The Great Republic 304 (1977).

103. See BAILYN, supra note 102 , at $611-13,774-77$. 


\section{B. "Cases to Which the States Are Separately Incompetent"}

We turn now to the idea that the federal government may legislate in cases "to which the states are separately incompetent." I take it that the notion of the states' being "separately incompetent" encompasses more than just those cases where Article I, Section 10, or some other part of the Constitution, specifically forbids the states from legislating. The authors of the Constitution were looking for solutions to practical problems. It was the practical incompetence of the states to deal separately with certain problems that was relevant to thinking both about what powers the federal government should have and about what limitations should be imposed on the states. So, the key question is, in what kinds of cases are the states practically incompetent despite possessing apparently sufficient legal power?

\section{Wickard v. Filburn and the Prisoner's Dilemma}

Let us start with the most straightforward case, Wickard $v$. Filburn. ${ }^{104}$ What interests me at the moment is not the proposition for which Wickard is famous - that if the aggregate of instances of a certain kind of behavior is an appropriate subject for federal regulation, then the federal government may regulate the individual instances. ${ }^{105}$ This proposition is extremely important and also, to my mind, utterly obvious, though it is convenient to have a standard citation for it and to be able to refer to it as "the principle of Wickard." But what I am interested in at present is the question why the federal government is appropriately concerned with the aggregate involved in Wickard. Why is it appropriate for the federal government to step in to limit agricultural production? The answer suggested by our current habits of Commerce Clause analysis, that the level of agricultural production affects the quantity of crops that flow across state lines, is inadequate. By itself, this is simply not a reason for federal intervention. What business has Congress to make a primary decision to limit the interstate flow of wheat any more than to limit the interstate flow of lottery tickets?

The real reason federal intervention is justified is that the problem of agricultural overproduction and consequent low prices - or, depending on how it works out, the problem of extremely volatile production and prices - is a problem the states are, practically speaking, incompetent to deal with separately. At least with regard

104. 317 U.S. 111 (1942).

105. See 317 U.S. at 127-29. 
to any crop that is grown in significant quantity in a number of states, an individual state is powerless to help its growers by limiting production in that state. If production is not limited in other states, aggregate production will still be high, prices will still be low, and the growers in the state that limits production will merely have less to sell, at the same low price. To be sure, the price may not be quite as low as it would have been in the absence of limitation by that state, but the trade-off is likely to be unfavorable because the growers in that state will have borne all the burden of producing whatever price rise is achieved and will reap only a small part of the benefit.

Even if all the states that produce significant quantities of wheat, for instance, agree that limiting production in order to raise or stabilize prices is a good thing, they will find it difficult or impossible to achieve their common goals by rational independent choices. In all probability, they face a strict multiperson prisoner's dilemma. Each state does the best it can for itself by not limiting production, regardless of what the others do, but all would be better off if they all limited production. Even if the prisoner's dilemma is not perfect because there is some circumstance in which some state is better off limiting production given the behavior of the other states, it is unlikely that general limitation is an equilibrium solution, so some "cooperation" is required if general limitation is to be achieved.

But cooperation is difficult, and it may not be an appropriate solution in a case like this, even if it is possible. As to the difficulty, it is a commonplace that cartels are hard to maintain. The members of the cartel have an incentive to cheat. In this case, where the contribution of each state to the cartel requires it to enforce limits on production within its own borders, it would be virtually impossible for the states to monitor each other. In any event, even if cooperation is possible, it may be objectionable. An explicit agreement among the wheat-growing states to hold down production might well violate the prohibition on interstate compacts. ${ }^{106}$ It is certainly the sort of behavior that would arouse the resentment of other states and threaten to interrupt "the harmony of the United States." I suspect that such an interstate cartel would be much more resented than the sort of single-state cartelization of raisin production that gave rise to Parker v. Brown, ${ }^{107}$ though even the

106. See U.S. ConST. art. I, \& 10, cl. 3.

107. 317 U.S. 341 (1943). 
latter may be enough of a threat to harmony among the states to justify federal supervision.

In sum, limiting production in order to raise or stabilize the price of a crop grown in a number of states is something the states cannot do separately. If it is to be done, the federal government must do it. That is the justification for federal regulation, if Congress decides the goal is worthy.

One never knows how one is going to be misunderstood. Let me emphasize, therefore, that I have not suggested the absurd view that if something, such as limiting production to raise crop prices, can be done effectively only by Congress, then Congress ought to do it. I have said only that if the regulatory problem has a structure that makes the states separately incompetent to deal with it, then it is proper for Congress to take up for itself the question whether something should be done and to do what it decides is wise. Even if all the wheat-growing states want congressional help in establishing a cartel, Congress is not obliged to help them. A fortiori, Congress is not obliged to act if the wheat-growing states are divided, as they may be because they all include consumers of wheat as well as growers. In the extreme case, if no wheat-growing state wants the cartel, Congress should not regard itself as being authorized to intervene. The underlying structure of the problem is unchanged, but intervention cannot be seen as facilitating any state's choice. But then, if no wheat-growing state wants the cartel, Congress is unlikely to be inclined to establish it.

The reader may be wondering how we know what the states want, when, by hypothesis, the structure of the situation may deter them from passing laws that embody their wants. The primary answer is that members of Congress are well attuned to political currents in their home states. If Congress considers seriously what the states want and what they do not, we can rely on Congress to get the right answer. In addition, the states, if they tire of waiting for Congress to notice their wants, can pass resolutions asking for congressional action. They cannot force Congress to act, but they have ways to make their wants known without passing useless or selfdestructive laws.

Two final points about Wickard. First, it may seem that I have been rather cavalier about the precise structure of the coordination problem facing the agricultural states. Is it, or was it in 1942, a strict multiperson prisoner's dilemma or only a general approximation of one? Just how difficult would cooperation between the states have been, with or without an explicit agreement? These are questions I 
think Congress should take seriously, as should scholars attempting to assist Congress's deliberations about whether federal intervention in some area is really needed. But they are not questions we need to worry about in the present context, where my object is to illustrate a general approach. Nor are they questions I think the Court would ever need detailed answers to for purposes of reviewing federal legislation for constitutionality. The general structure of the problem of agricultural price-regulation clearly makes it plausible that federal intervention may be necessary if the states' goals are to be achieved. That, plus a congressional decision to intervene, should normally satisfy the Court.

Second, I have suggested that Congress may appropriately assist the agricultural states to establish a "cartel." The word is an expository convenience, but for some readers it will also be a red flag. Aren't cartels a bad thing? Should we be interested in finding a justification for Congress's helping to establish them? If our federal structure makes it harder for states to establish cartels, the thought continues, so much the better; Congress should keep its hands off, to preserve the benefit. The short answer is that cartels are not always a bad thing; labor unions, for example, are widely approved. Even if cartels are a bad thing, there is nothing in the Constitution that says so, or that makes any such belief binding on the states or Congress. Of course, if there were something in the Constitution that forbade states from attempting to improve the lot of farmers by limiting production, then we could not justify federal intervention on the ground that it was the only way states could achieve that goal. But in fact, the states are free to have this goal, and the nature of the problem is such that if they have the goal, Congress may properly help them achieve it.

\section{Darby and Wage Regulation, Usery and the Tenth Amendment}

United States v. Darby ${ }^{108}$ presents a similar but slightly more complex situation. I suggested in connection with Wickard that a state that tried to raise agricultural prices by unilateral limitation of production simply could not do it, in all probability. In contrast, a state that imposes a minimum wage for its manufacturing workers can ensure that those workers are paid what it requires. Even so, a state that acts alone in imposing a minimum wage may well suffer significant adverse consequences, which would be avoided by joint action. If we assume that the higher wage will be reflected in higher

108. 312 U.S. 100 (1941). 
prices, then a state that raises wages unilaterally will cost its manufacturers business in the short run, insofar as the manufacturers compete with firms in other states that have not imposed similar minimum wages, and the state may lose its manufacturing base to other states in the longer run.

So, states are free in principle to regulate wages as they please, to have a minimum wage or not. But in practice, the fact of belonging to a federal system makes it much less attractive for any individual state that wants a high wage to impose it. So long as there are a significant number of low-wage states, there will be a significant disincentive for the states preferring high wages, even if they are numerous, to put their views into effect, because their goods must compete against goods from low-wage states in every state's consumer market. ${ }^{109}$

This seems to me, no less than Wickard, a case in which the states are, practically speaking, "separately incompetent." If membership in the federal union significantly impairs a state's ability to do in practice something, such as raising wages, which it is perfectly free to do in principle and which it is no part of the object of union to restrain it from doing, then there is every reason to regard the federal government as vested with power to act on the state's behalf.

But suppose the states are divided, some preferring high wages, some not. If Congress adopts a national minimum wage, the freedom of the low-wage states to put their views into practice will be even more thoroughly suppressed than was the freedom of the high-wage states in the absence of federal legislation. That is true, but at least the low-wage states will have had a chance to contest the issue, through their representatives in Congress. If low-wage states are the majority, they will probably prevail. In contrast, if there is no federal power, the would-be high-wage states suffer impairment of their freedom without the chance to put the matter to any sort of common deliberation, and they may suffer significant impairment even though they are in the majority.

109. I shall refrain from including, even in a footnote, a long discussion that would probably interest nobody but me about (1) whether a high-wage state could, consistently with the dormant Commerce Clause, close its borders to goods made in other states under substandard conditions, and (2) whether, if it could go that far, it could, consistently with the Interstate Compacts Clause, join together with other high-wage states to allow free movement of goods among themselves but jointly exclude goods made elsewhere under substandard conditions. Most of my readers would assume the answer to both of these questions is obviously, "No." I do not think the answers are so obvious, especially to the first question, but I shall bow in the present context to the general assumption, which merely strengthens the case for federal power. 
Congress also has available a middle road. Instead of promulgating a national minimum wage, Congress could protect the interests of high-wage states by prohibiting the introduction into those states of goods manufactured under substandard conditions, with the standard no higher than whatever the state imposes on itself. Congress once passed laws of this form. ${ }^{110}$ An argument could be made that, as a matter of principle, Congress should prefer to deal with problems like the minimum wage in this fashion. If Congress legislates in this mode, and can enforce the legislation, then goods from high-wage states will not have to compete with goods from low-wage states in their own home markets or in the market of any other high-wage state. They will still have to compete with goods from low-wage states in the markets of the low-wage states, and that will be some disincentive to imposing a minimum wage. But that particular disincentive is not one that can be blamed on membership in the federal system; it would exist equally if the states were completely independent sovereigns. Still, the difficulties of enforcing the ban on transportation may be such that even a conscientious Congress, preferring in principle to legislate in the statespecific form, could decide that the only really practical way to deal with the problem on behalf of the high-wage states is to enact a national minimum wage. If the high-wage states have the numbers to secure Congress's assistance, Congress has the power.

Just as in the discussion of Wickard, it is neither essential to my project, nor, I think, to responsible decisionmaking by the Court, that we try to pin down the precise degree of disincentive to the high-wage states that must exist if there is to be federal power. Nor do we need to worry now about whether the practical difficulty in enforcing a specific ban on introducing low-wage goods into highwage states is enough to justify Congress in eschewing that approach. Such questions are important, but they are for Congress; they are not for the Court or, right now, for me.

On the other hand, it is important that the basic structure of the problem be as I have described, and that points to an issue about how broadly to characterize the problem. For example, I would say that here we should treat as "the problem" not wage levels in general, but the wage level in a particular area of the economy. Different areas generate different problems. It was a crucial assumption of our schematic presentation that goods from high-wage states compete with goods from low-wage states. The argument for fed-

110. See, e.g., Kentucky Whip \& Collar Co. v. Illinois Cent. R.R., 299 U.S. 334 (1937). 
eral power, even in its schematic form, does not apply when there is no interstate competition. Many service industries - restaurants, laundries, and so on - sell in essentially local markets. The argument we have been considering suggests no justification at all, so far as I can see, for federal regulation of wages at, for example, McDonald's. ${ }^{111}$

Before we go on to consider another issue about the scope of this argument for Darby, I want to say a word about Justice Stone's opinion for the Court and its reception. Justice Stone makes two different sorts of argument for the federal minimum wage. The first argument is in two stages. Justice Stone begins by asserting that Congress may prohibit the crossing of state lines by goods made under any conditions Congress disapproves; ${ }^{112}$ he then defends the direct prohibition of employment under such conditions, in the manufacture of goods for interstate shipment, as a necessary and proper means to guarantee the success of the prohibition on line crossing. ${ }^{113}$ In his second argument, Justice Stone talks about Congress's power to prevent the spread of evils by the mechanism of interstate commerce and their power to prevent "unfair competition."114 Justice Stone's first argument has nothing to do with a proper approach to the commerce power. It is a mistake to read the Commerce Clause as giving Congress an unrestricted power to regulate movement across state lines;"115 and the "necessary and proper" step in the argument has no purchase in the absence of some prior argument that justifies Congress in doing something. In contrast, Justice Stone's argument about spreading evils and unfair competition, unclear though it is, is at least open to interpretation as the argument that I have suggested really does justify federal minimum-wage regulation. Unfortunately, it is Justice Stone's first argument that tends to be remembered and appealed to, not his second. I fear there is an analogue of Gresham's Law in operation. Bad doctrine drives out good. It does so because, in this area at least, the bad doctrine is easier to manipulate mindlessly.

111. It is possible, of course, that some other argument, yet to be considered, would justify this, though I am skeptical. The only colorable candidate I can think of stresses the difficulties states may have in regulating large multistate corporations. See infra section III.B.4.a. That McDonald's buys supplies in interstate commerce is not an adequate justification. See infra notes 143-44 and accompanying text. The point for now is just that the argument of Darby does not apply to McDonald's, or to any firm that sells in localized markets.

112. See Darby, 312 U.S. at 115-20.

113. See 312 U.S. at 120-23.

114. See 312 U.S. at 122.

115. See supra notes $93-95$ and accompanying text. 
Now back to cases. If the Darby argument does not justify a federal minimum wage at McDonald's, no more does it justify a federal minimum wage for state and local police and fire departments. In National League of Cities $v$. Usery, ${ }^{116}$ both the majority and the dissent assumed with little discussion that the commerce power, considered on its own, extends to imposing a minimum wage for police and fire departments. The disagreement was about whether the Tenth Amendment erects a special barrier to regulation of traditional and integral state functions. The majority found a Tenth Amendment barrier, which it was obliged to abandon nine years later in Garcia v. SAMTA. ${ }^{117}$ The majority would have done better to deny that the commerce power itself encompassed this regulation.

To be sure, there is not much room for doubt that the commerce power extends this far if we rely on standard doctrine. I assume there is enough mobility in the labor markets for police and fire personnel so that comparative wages "substantially" affect the movement of persons across state lines. But I do not see why this, by itself, suggests any special need for federal intervention. Surely interstate movement of persons as such is not a problem. Further, at least at the first level of analysis, the existence of low-wage states does not undercut the ability of high-wage states to pay high wages in the way it did in Darby. State-provided police and fire protection services are not shipped across state lines. The high-wage states face no impediment to paying whatever wages they please. If anything, low wages elsewhere should benefit the high-wage states by increasing the range of candidates from which they can hire.

The existence of low-wage states may be bad for police and fire personnel in other states because low wages in one state put no pressure on other states to raise wages, as higher wages in the first state would. It comes as no surprise that police and fire personnel have an interest in high wages being paid for such work everywhere. But, barring some special provision such as the Fourteenth Amendment, it cannot be an adequate reason for federal intervention that it would help particular interests in the states achieve their goals. This would make federal power limitless. As long as the states can choose as freely within the federal union as without it whether to respond to those interests, the states should be left to

116. 426 U.S. 833 (1976).

117. Garcia v. San Antonio Metro. Transit Auth., 469 U.S. 528 (1985). 
decide. Usery and Darby are very different cases on pure Commerce Clause grounds. ${ }^{118}$

There are some further complications. I have suggested that in this particular part of the economy, police and fire protection, the existence of low-wage states puts no pressure on high-wage states to reduce wages. But if the relevant labor force is mobile, the existence of high-wage states does put pressure on low-wage states to raise wages. So it may be that, while a high-wage state is free to choose as it wants, a low-wage state finds its freedom of action significantly constrained. Is this a justification for federal intervention?

Notice first of all that if this is a justification, it is a justification for federal imposition of a maximum wage, not a minimum wage. It is the low-wage states, not the high-wage states, whose freedom needs protection, and the appropriate mode of protection, to relieve the pressure from high-wage states, is a maximum wage. Of course, if a maximum wage is imposed, that will to some degree restrict the freedom of high-wage states; so, as I said in discussing Wickard, there is a real decision for Congress to make about whether to help the low-wage states. But if Congress does help them, the resulting restriction on the freedom of the high-wage states is not one that will be ameliorated by imposing a minimum wage in addition to the maximum, so we still have no justification for a minimum in this sort of case.

I have elaborated this argument, not because I favor a maximum wage for police and fire personnel or because I think Congress is likely to impose one, but to point out again that different problems are different problems. There may be the right sort of justification for imposing a maximum wage, if that is what Congress wants to do, without there being the right sort of justification for imposing a minimum wage. (And in other contexts, vice versa.) So we should ask, not "Does Congress have the power to regulate wages?" but more specifically, "Does Congress have the power to

118. There is room in Usery for a more complicated argument on how states with low wages in the public sector undercut states with high wages. High-wage states, the argument goes, must pay for their high public-sector wages with relatively high taxes; low-wage states can have lower taxes. The higher taxes in high-wage states will make private businesses that do compete across state lines either less competitive or less profitable, so that businesses will prefer states with low wages and low taxes. I am inclined to say that given the number of factors that contribute to determining levels of taxation, the disincentive to paying high wages in the public sector is just too slight and attenuated. But my view about this could be changed by a strong factual counterargument if such is available. In any event, this seems to me the only way to argue under the Commerce Clause for a federal minimum wage for state and local police and fire protection personnel. 
regulate these wages in this way?"119 Even if we are quite deferential to Congress, as I think we should be, it may sometimes make a difference to the result whether we ask the right question. It will certainly make a difference to Congress's own deliberations whether they ask the right question.

Let us pause now for a brief detour through the jurisprudence of the Tenth Amendment. I have argued that the commerce power does not extend to imposing a minimum wage on state and local police and fire personnel and that therefore the result in Usery was right. I suggested earlier that Garcia v. SAMTA, which overruled Usery's Tenth Amendment theory, was also right on its facts because it involved regulation of an element of the national transportation network, though its Commerce Clause theory is no better than Usery's. ${ }^{120}$ Where does this leave the Tenth Amendment, which was the focus of the argument in both cases?

In my view, the Tenth Amendment is a "truism," as Justice Stone famously asserted, ${ }^{121}$ but it is a significant truism as opposed to a trivial one. The Tenth Amendment imposes no limitation on the scope of federal power that is not otherwise inferable from the history, text, and structure of the Constitution. If the Tenth Amendment were not there, the meaning of the Constitution would be unchanged. On the other hand, the Tenth Amendment is a re-

119. I have been arguing that if the pressure imposed by high-wage states on low-wage states is a justification for federal intervention, it is a justification only for a federal maximum wage. But is it a justification at all? I am much less comfortable with the argument here than with the argument for a federal minimum wage in manufacturing. I admit that my different response may be pure prejudice in favor of higher wages and better conditions for municipal workers. There is, however, at least one colorable argument for a distinction of principle. Insofar as high-wage states put pressure on low-wage states, it is by attracting immigration. The high-wage states are competing for people with certain skills or inclinations, and they are competing for those people by making themselves more attractive places, all things considered, for them to live. This sort of competition, between states trying to make themselves attractive places for people they want, seems more in keeping with the spirit of the union than competition for trade waged by sending goods produced under conditions other states disapprove of into those other states' markets. Therefore suppressing the competition for people seems a less plausible justification for federal intervention.

If I am pressed to explain further, I revert to the idea that in joining the union, states made it more difficult for themselves practically and perhaps legally, see supra note 109 and accompanying text, to close their borders to imported goods made under conditions they disapprove. In return, they can reasonably expect at least the possibility of federal protection. In contrast, their only protection against competition for people, even in the absence of union, would have been restrictions on emigration. The separate sovereign states would have had the legal power to forbid emigration, at least so far as their interstate relations were concerned. (Whether the state constitutions would have been thought to allow this, I do not know.) But this power seems much less like one the states would have exercised even in the absence of union. If so, it is not a power they gave up in the same way upon entering the union, or for which they deserve a chance at securing a federal substitute.

120. See supra text accompanying note 87 .

121. See United States v. Darby, 312 U.S. 100, 124 (1941). 
minder of what those other sources reveal: that the federal government was not endowed with all the powers of the government of a unitary nation. This is a reminder we obviously still need because our present approach to the Commerce Clause pays this fact no more than lip service.

If the Tenth Amendment is a truism, has the Court been mistaken to retain a certain residue of Usery's Tenth Amendment doctrine in New York v. United States? ${ }^{122}$ Not at all. I am not sure whether I think New York $v$. United States was correct in its result - I vacillate about the propriety of the "take title" alternative or some equivalent - but the idea it represents, that the federal government may not commandeer the political institutions of the states, seems indisputable.

It would be much more sensible, however, to assign this idea to the Necessary and Proper Clause rather than to the Tenth Amendment. Roughly speaking, the Tenth Amendment addresses, truistically, the question of what kinds of thing Congress may regulate. The Necessary and Proper Clause addresses the question of what means Congress may use to achieve its regulatory ends. Nobody doubted in New York $v$. United States that Congress could regulate radioactive waste; nor do I doubt it, though I have not yet discussed the most relevant sorts of argument. The only issue was about the means Congress had chosen. The Necessary and Proper Clause suggests, by implication, that some means are improper. If we think the means Congress used in this case were improper, this seems the natural clause to appeal to. ${ }^{123}$

One last issue about the Tenth Amendment. If we decide that the Tenth Amendment is in one respect a truism and in another respect a mistaken assignee of functions of the Necessary and Proper Clause, how does it interact with the Reconstruction Amendment enforcement powers? Is the situation parallel to the

122. 505 U.S. 144 (1992).

123. As I have said in another essay on another subject, Donald Regan, Siamese Essays: (I) CTS Corp. v. Dynamics Corp. of America and Dormant Commerce Clause Doctrine, (II) Extraterritorial State Legislation, 85 MrCH. L. REv. 1865, 1887-95 (1987), it does not matter ultimately to what clause we assign these basic structural ideas, nor whether we assign them to any clause at all. What is important is to be clear about the ideas and to avoid confusing ourselves by attaching too much significance to any assignment. Deborah Jones Merritt has suggested assigning the prohibition on commandeering to the Guarantee Clause, which sounds fine. See Deborah Jones Merritt, Republican Governments and Autonomous States: A New Role for the Guarantee Clause, 68 U. CoLo. L. Rev. 815 (1994). Note, however, that it can matter where we assign some idea if it will interact with other bits of doctrine already attached to the possible locuses of assignment. See, for example, Regan, supra note 77, at 1202-06, 1277-78; and Terrance Sandalow, Constitutional Interpretation, 79 MicH. L. Rev: $1033,1055-60$ (1981). 
situation with the commerce power, or different? The answer is that the Reconstruction Amendment enforcement powers differ from the commerce power with respect to both the "truistic" scopeof-power aspect and the "necessary and proper means" aspect of the Tenth Amendment.

With regard to the scope-of-powers aspect, remember what we said about lotteries and could have said about agricultural production or wage regulation: if the states can effectively pursue their independent policy choices in these areas, they should be left to do so. It is only because the states may be unable to make their policies effective that Congress has any business having a policy with regard to these matters. But the Reconstruction Amendments make specific policy choices, which Congress is authorized, and indeed obligated in conscience, to use its enforcement powers to promote. Even if the states could make their individual decisions about whether to engage in race discrimination, for example, fully effective, Congress would not thereby be deprived of grounds for intervention. So we should not think about the scope of the enforcement powers the same way we think about the scope of the commerce power. ${ }^{124}$

With regard to the "necessary and proper means" issue, the important point is that much legislation under the enforcement powers is remedial, occasioned by the states' misbehavior. A variety of measures, including measures that involve some commandeering of state institutions, may be necessary and proper as remedies for state misbehavior which would not be appropriate as means for the promotion of just any congressional policy. For example, I think Congress's power to legislate for the safety of the interstate transportation system would allow it to create and administer a national system for licensing drivers. But that does not mean Congress could deal with what it viewed as inadequate standards in the state licensing systems by sending in federal officials to administer the state systems, as it did with voter registration under the Voting Rights Act of $1965 . .^{125}$

124. This obviously does not mean the enforcement powers are unlimited. Only that we must think in a different way about where the limits are.

125. Voting Rights Act of 1965, Pub. L. No. 89-110, 79 Stat. 437 (codified as amended at 42 U.S.C. § 1973-1973bb-1 (1988)). 


\section{Katzenbach v. McClung: A Hard Case That Made Bad Doctrine}

There are other arguments we have not yet considered that can show the states need federal help to accomplish their ends in certain kinds of cases. Indeed, so far we have only picked off the neatest arguments, which seems perfectly appropriate for illustrative purposes. But before we go on, I want to pause over some bad arguments. If we do not identify these bad arguments and dismiss them, they will tend to confuse our view of the cases that illustrate the remaining good arguments.

Katzenbach v. McClung ${ }^{126}$ is a veritable catalogue of bad Commerce Clause arguments, with one or two colorable arguments entangled in the mess. Certain of the arguments in McClung represent the final corruption of Commerce Clause doctrine. Let me say immediately, I approve of the result in $\mathrm{McClung}$. Indeed, McClung was one of those cases in which a particular result was both morally and politically necessary. If constitutional doctrine had to be deformed to achieve the result, then the deformation was justified. But I do not think deformation was necessary. If it was, then what should have been "deformed," and improved, was the doctrine of the Civil Rights Cases, ${ }^{127}$ which was itself a disfigurement, hallowed only by the passage of eighty years.

It is not necessary to decide for present purposes whether the Court in $\mathrm{McClung}$ should have anticipated the Thirteenth Amendment argument of Jones $v$. Mayer; ${ }^{128}$ or held that the state was literally "denying equal protection" when it left unprotected for African Americans a right of access to public accommodations that was guaranteed to whites by the common law; or held that Congress's power to enforce the Equal Protection Clause was broader than the judicially enforceable content of the clause; or held that Congress when it passed Title $\mathrm{II}^{129}$ was enforcing the grant of citizenship, either federal or state, in the first sentence of the Fourteenth Amendment. What is clear is that the Court should have based its holding on the Reconstruction Amendments in some way or other.

Is this merely the argument of a Commerce Clause obsessive? It may seem that if I am not prepared to expound and defend some particular Thirteenth or Fourteenth Amendment argument as cor-

126. 379 U.S. 294 (1964).

127. United States v. Stanley, 109 U.S. 3, 17 (1883).

128. 392 U.S. 409 (1968).

129. Civil Rights Act of 1964, tit. II, Pub. L. No. $88-352,78$ Stat. 243 (codified as amended at 42 U.S.C. $\$ 2000$ (a) (1988)). 
rect and available in 1964, then I am merely saying the Court should have deformed the law of the Reconstruction Amendments rather than the law of the commerce power. Actually, that is precisely my claim in the context of this case. I have said that the result the Court achieved in McClung was necessary. But what sort of considerations made it necessary? Was it considerations involved with the general thrust of the Commerce Clause or considerations involved with the general thrust of the Reconstruction Amendments? The answer to that is obvious enough. It seems equally obvious that we will develop more sensible doctrine in the long run if, when some deformation is required to achieve a necessary result, we deform the doctrines that involve the considerations that generate the necessity. ${ }^{130}$

Time now to justify the claim I have been presupposing, that taken as a whole, McClung is a disaster as a Commerce Clause precedent. The Court in $M c C l u n g$ made or adumbrated quite a grabbag of Commerce Clause arguments, from which it is worth isolating at least the following: (1) Because Ollie's Barbecue bought a significant amount of food in interstate commerce, discrimination by Ollie's reduced the flow of commerce across state lines. ${ }^{131}$ (2) Discrimination by Ollie's impeded the access of African Americans to goods moving in interstate commerce. ${ }^{132}$ (3) Discrimination by Ollie's and other businesses contributed in various ways to a lower level of general business activity and productivity in Alabama, thereby decreasing the flow of all kinds of goods into and out of Alabama.133 (4) Because a significant part of Ollie's food had crossed a state line, Congress was entitled to regulate all further dealings with that food. ${ }^{134}$ (5) Discrimination by Ollie's and other similar restaurants made life more difficult for African-American interstate travelers in Alabama.135 (6) Discrimination by Ollie's and other restaurants contributed to a social pattern of discrimination that discouraged immigration into Alabama from other

130. No doubt the Court in 1964 not only regarded the result as necessary, but thought it would be less politically incendiary to appeal to the Commerce Clause to justify Congress's power. I am not sure how much difference the prevarication made to the political reception of the case, but the Justices of the Court were both more attuned to the political culture of that time and more politically astute than I. Still, we do not have to second-guess them on the decision they made then to recognize now that as a Commerce Clause decision McClung was a mistake, and to repair the damage by reanalyzing it.

131. See Katzenbach v. McClung, 379 U.S. 294, 299-300 (1964).

132. See 379 U.S. at $299-300$.

133. See 379 U.S. at $299-300$.

134. See 379 U.S. at 302.

135. See 379 U.S. at 300. 
states. ${ }^{136}$ Of these arguments, only the fifth, and possibly the third, provide even a colorable Commerce Clause justification for congressional intervention.

Let us consider the arguments in turn:

(1) Supposing that discrimination by Ollie's reduced the flow of food into Alabama, so what? What business of Congress's is this? It is unquestionably Congress's business to promote the possibility of interstate commerce by guaranteeing the existence of an effective transportation network and the like. The possibility of trade increases the states' abilities to make effective choices, in addition to making them a nation. But it does not follow that Congress is justified in doing anything it chooses that will cause more goods to move across state lines. Can Congress forbid the game of golf just because doing so will make the people of Florida watch more Hollywood movies? Can Congress prevent Michigan from restricting smoking in public places just because doing so will increase the flow of cigarettes from North Carolina? To be sure, Michigan's restrictions on smoking interfere with North Carolina's project of selling more cigarettes. But they do not interfere with North Carolina's own decision about whether to restrict smoking or not. The states' decisions do not interact as they did in Wickard or Darby. Michigan is entitled to do as it wants. Congress has no warrant to intervene just because some feature of the culture of a state makes it a less eager purchaser for some, or all, goods from other states. ${ }^{137}$

But, you are no doubt thinking, the particular feature of the culture of Alabama that was involved, racism and race discrimination in public accommodations, is not one Alabama is entitled to; it is not like a preference for golf over movie-going or for smoke-free restaurants. Of course that is true. But it is not the Commerce Clause that says so. It is the Reconstruction Amendments. The Commerce Clause argument is inadequate until we appeal to the Reconstruction Amendments, and once we look there, the Commerce Clause argument adds nothing. The Commerce Clause is irrelevant.

(2) The same basic point applies to the suggestion that discrimination by Ollie's denies the excluded individuals access to interstate commerce. There is no general right of access to interstate commerce, even in the sense of a right Congress may recognize and

136. See 379 U.S. at 300.

137. Unless of course the state is acting in a protectionist manner. See the discussion infra notes 139-41 and accompanying text. 
protect if it chooses. A state may forbid the importation, along with the local manufacture, of course, of fireworks. Or it may discriminate among its people, forbidding the importation of fireworks for sale to persons under eighteen years of age. Or, a fortiori, the state may allow individual retailers of the sort who might sell fireworks in other states to decline to sell them or to decline to sell them to minors. Congress would have no business overriding any of these state choices on the ground that individuals in the state were denied access to interstate commerce in fireworks. ${ }^{138}$

No more do African-American citizens of Alabama have a right of access to interstate commerce. What they do have is a right of equal access with the white citizens of Alabama. That is the right Congress is empowered to protect - again, not by the Commerce Clause, but by the Reconstruction Amendments.

There is a possible variation on this "access to commerce" argument: that the Reconstruction Amendments established a new general interest of the union in the integration of African Americans into the national economic life. ${ }^{139}$ If this is recognized as a general interest, Congress is obviously free to act on it because many states have been opposed or at least indifferent to the interest. Like some of the Reconstruction Amendment arguments I mentioned earlier, this argument has the advantage of finessing the state action requirement. It goes further than the other arguments in shifting the focus entirely away from any claim about individual rights, a move that can seem both appealing in some ways and unappealing in others. In any event, what we are left with is a hybrid Commerce Clause-Reconstruction Amendment argument. The Commerce Clause alone does not suffice, and the reach of the argument is limited by what we can plausibly view as "general interests" established by the Reconstruction Amendments.

(3) The same basic point applies to the argument that discrimination lowers productivity and general business activity, making Alabama a less desirable trading partner for the other states. This empirical claim is highly plausible. But it provides a very problematic ground for congressional intervention. In general, the states are not required to be the best possible trading partners for each other. They are required, of course, not to be bad trading partners in certain ways. They are forbidden to engage in protectionism

138. In case some reader thinks there is a constitutionally protected liberty to use fireworks, this is a substantive due process argument, not a Commerce Clause argument.

139. This variation was suggested to me by discussions with Kendall Thomas and Terry Sandalow. 
against other states. But to say the states may not discriminate against goods or economic actors from other states is not to say they must arrange their internal affairs so as to maximize trade with other states, or even to achieve some level of trade that Congress deems appropriate.

This distinction would make no sense if the only point of forbidding protectionism were to increase trade. But that is not the only point, nor really even a point. One point of forbidding protectionism is to eliminate a fertile source of contention and hostility between the states. Another point is to promote efficiency, which does not mean maximizing production and commerce, but means rather maximizing satisfaction of preferences. ${ }^{140}$ The relevant preferences are presumably expressed in the choices that states make or allow their citizens to make, and they sometimes lead to less production and commerce rather than more. ${ }^{141}$

Of course, we are not interested in promoting the efficient satisfaction of a preference, state or individual, for race discrimination. But, once again, it is the Reconstruction Amendments, not the Commerce Clause, that establishes that as a constitutional proposition. The appeal to the Reconstruction Amendments does all the work. The Commerce Clause adds nothing.

One way to make a Commerce Clause argument out of this is to suggest that race discrimination was causing such economic backwardness in the South that it threatened the general interest in the nation's economic health. If accepted, this move sidesteps the Reconstruction Amendments entirely. Whether this suggestion is really plausible - whether the threat to our national economic health was sufficiently severe to justify a conscientious Congress in overriding a state choice that, if we make no appeal to the Reconstruc-

140. See Regan, supra note 77 , at $1115-24$.

141. But does not a state tariff or embargo on out-of-state goods express a preference? Yes, but it is still importantly different from, say, laws against smoking in public places. States do not normally have an intrinsic preference for in-state goods; they adopt protectionist measures to enhance their economic success. The trouble is that when everyone does it, it is self-defeating. Smoking restrictions are more likely to reflect an intrinsic preference, and even to the extent they are extrinsic and aimed at, for example, health, they are not selfdefeating when generally adopted. We could imagine, of course, that some state really has an intrinsic preference for local goods, and one strong enough to make it willing to accept the loss from widespread protectionism. At that point, the answer must be that the state gave up the right to act on this particular preference when it joined the union - just because protectionist preferences are so disruptive to interstate relations and so likely to be extrinsic and collectively self-defeating. 
tion Amendments, must be regarded as permissible - I do not pretend to know. But at least this argument is possible. ${ }^{142}$

(4) The argument that Congress can regulate all aspects of the business of Ollie's Barbecue because it buys food in interstate commerce is so implausible in this general, abstract form that I hardly know how to discuss it. There may be some cases in which the fact that something has moved in interstate commerce seems relevant to whether Congress can regulate it. For example, if the object in question is dangerous to human health, then it might be said that Congress must be able to attack the danger after the shipment and not merely to try to prevent the shipment. But even here it seems to me we should ask the question whether the states cannot adequately protect themselves against the danger by individual legislation. To ask that question, even in the case of a "dangerous" object, is not pointless formalism about federalism. Dangers come in degrees, and there are always questions both about what are effective means to alleviate the dangers and about what means are worth taking, given their costs. There is no justification for federal displacement of state views about these questions unless, for some reason of the sort we are canvassing in this essay, the states individually cannot make their views effective.

But the goods in question in $\mathrm{McCl}$ (ung are not dangerous. Nor is there any other reason to think that their availability to Ollie's through interstate channels creates a problem the state is unable to deal with. The real problem, I repeat monotonously, is that the state did not see as a problem something that the Reconstruction Amendments either obligated or at least authorized Congress to treat as a problem, namely, race discrimination in privately run restaurants. That has nothing to do with the Commerce Clause, nor indeed with whether Ollie's has bought anything at all that originated out-of-state.

The idea that Congress can regulate whatever has moved across a state line has become a popular "hook" for federal legislation. It is a crucial support of much of the federal law on firearms possession, to take an example close to home. ${ }^{143}$ But it is none the better argument for that. ${ }^{144}$

142. We could also argue that the denial of economic opportunity to African Americans both makes it harder for them to achieve educational goals and lessens the incentive for them to do so, thus threatening the general interest in an educated national citizenry touched on supra in section III.A.2.

143. See supra note 60.

144. A curious wrinkle: sometimes federal regulation of behavior regarding something that has moved across a state line might be necessary to reassure the originator of the inter- 
(5) What of the argument that discrimination by Ollie's and other restaurants made life more difficult for African-American interstate travelers in Alabama? Formally, this is a perfectly good argument. I have already suggested that it can support federal regulation of the Heart of Atlanta Motel. But Ollie's was not the Heart of Atlanta. There was no evidence that Ollie's served any interstate travelers, nor any reason a priori to expect that it would, given its location many blocks from any interstate highway. ${ }^{145}$ Nor does appeal to the principle of Wickard help. What that principle must be taken to say is that Congress may regulate Ollie's if the aggregate of the behavior of all restaurants like Ollie's has an effect on interstate travelers. But if Ollie's serves no interstate travelers, then the aggregate of all restaurants like Ollie's serves no interstate travelers, and there is still no ground for federal intervention.

The one suggestion that might help here is the claim that it is too difficult or too costly to distinguish between restaurants that serve some interstate travelers and those that serve none. Therefore, Congress can lump all restaurants together, and because that aggregate does serve interstate travelers in significant numbers, Wickard justifies federal intervention. This sort of argument has much plausibility in a case like Perez $v$. United States, ${ }^{146}$ where it might be unreasonably difficult to distinguish between local loan sharks who have no connection to interstate organized crime and those who do have such a connection. But loan-sharking is a clandestine activity, and dealings with organized crime even more so. Serving customers in a restaurant, in contrast, is necessarily public. It would not have been difficult to find evidence of Ollie's interstate custom if it had had any. The "burden on travel" argument, as applied to Ollie's, is strained at best.

(6) The final argument is that the general climate of discrimination in Alabama discouraged immigration into Alabama from other states. As with some of the other arguments, the empirical claim seems plausible, but it is irrelevant. Congress has no more justification for doing whatever will increase the movement of persons across state lines than it has for doing whatever will increase the movement of goods across state lines. To put the point from the

state shipment about how the thing will be treated at its destination, because without the reassurance the originator might be unwilling to send the thing into another state. This is a conceivable justification for making the federal law on treatment of laboratory animals cover animals that have been shipped in interstate commerce. See 7 U.S.C. $\$ \$ 2131-59$ (1994) ("Transportation, Sale, and Handling of Certain Animals").

145. See Katzenbach v. McClung, 379 U.S. 294, 296 (1964).

146. 402 U.S. 146 (1971). 
states' perspective, a state has no more obligation to make itself attractive to immigrants than it has to make itself an active trading partner for other states. Since 1868, the states have undertaken to allow immigration. ${ }^{147}$ They have not undertaken to arrange their affairs so as to encourage immigration, and Congress has no general warrant to make them do so. Need I say again that if the behavior of Alabama that discouraged immigration into Alabama was constitutionally objectionable, as of course it was, it was not the Commerce Clause that made it so?

The urge to rationalize $M c C l u n g$ is powerful. Indeed, I have said myself that rationalizing McClung somehow is necessary. What I do not understand is why so many people want to rationalize it without reference to the Reconstruction Amendments. An argument $I$ have not even mentioned is that Congress was justified in passing the Civil Rights Act of 1964148 because race discrimination in the South was an embarrassment in our international relations. ${ }^{149}$ Formally, this argument is fully acceptable, but I have the same sort of doubts about it that I expressed earlier about the "remedying economic backwardness" argument.150

Even if one of the formally acceptable Commerce Clause arguments we have identified is adequate to justify $M c C l u n g, M c C l u n g$ has suffered the same Greshamic fate as Darby. The clearly bad doctrine has driven out the possibly acceptable, which is much narrower in scope. What $M c$ Clung is now relied on for is the general "affecting commerce" doctrine and the idea that Congress can regulate whatever has crossed a state line. Hence my claim that as a precedent it has been a disaster.

\section{Labor Relations, Food and Drugs, and Environmental Law}

If we are to do without the powerful and wide-ranging arguments that I have rejected in the discussion of McClung - the general "affecting commerce" argument and the "whatever has crossed state lines" argument - we must make sure there are adequate substitutes to justify some areas of federal regulation in which the kind of structural state incapacity we have seen in Wickard and Darby is either absent or less prominent.

147. See U.S. Const. amend. XIV, \& 1.

148. Civil Rights Act of 1964, Pub. L. No. 88-352, 78 Stat. 241 (codified as amended in scattered sections of 28 U.S.C. and 42 U.S.C.).

149. I was reminded of this argument in discussion with Andrzej Rapaczynski.

150. See supra text accompanying note 142 . 
a. NLRB v. Jones \& Laughlin and Labor Relations. In the first great case of the modern era of the Commerce Clause, $N L R B v$. Jones \& Laughlin Steel Corp., ${ }^{151}$ the Court upheld the application of the National Labor Relations Act $^{152}$ to a multistate, vertically integrated steel company. The Court seemed to put most reliance on the argument that work stoppages at Jones \& Laughlin could interrupt the flow of goods in interstate commerce. ${ }^{153}$ If what I said about Katzenbach v. McClung is right, then we should be very skeptical of this argument standing alone. The bare fact that some regulatory scheme would increase the flow of commerce, without reference to further context, is not an adequate justification for Congress's enacting that scheme.

The multistate organization of Jones \& Laughlin, which the Court emphasized, ${ }^{154}$ did make nonsense of the claim in Carter Coal $^{155}$ that manufacturing is an essentially local activity. But undercutting a bad argument against congressional power is not the same as supplying a good argument for it. Notice also that the "interrupts the flow of commerce" argument does not actually depend on the multistate organization of Jones \& Laughlin. So an aspect of the case that was given great rhetorical prominence in the recital of facts ${ }^{156}$ disappeared from the apparent rationale - which is why it became so easy to extend Jones \& Laughlin to small, local manufacturers. ${ }^{157}$

Of course, it is hard to doubt that Jones \& Laughlin was rightly decided. So what are the features of the case that make the result seem so obvious? One such feature is the multistate character of Jones \& Laughlin and also of the steelworkers union. These facts were important, even if the Court failed to explain why. Where the matter to be regulated is the ongoing relations of two large, multistate organizations, no individual state can deal effectively with even those behavioral elements of the relationship that are physically localized within its own boundaries. Neither the steel com-

151. 301 U.S. 1 (1937).

152. National Labor Relations Act, ch. 372, 49 Stat. 449 (1935) (codified as amended at 29 U.S.C. $\S \S 151-69$ (1988).

153. See 301 U.S. at $41-43$.

154. See 301 U.S. at 26-28.

155. Carter v. Carter Coal Co., 298 U.S. 238 (1936).

156. As I was writing this essay, I came across the following observation by Pat Gudridge: "In Jones \& Laughlin, for example, [Hughes's] opinion arguably established its conclusion by the time it finished stating the facts." Patrick O. Gudridge, Florida Constitutional Theory (For Clifford Alloway), 48 U. Miami L. Rev. 809, 814 (1994) (footnote omitted).

157. See, e.g., NLRB v. Fainblatt, 306 U.S. 601 (1939); NLRB v. Friedman-Harry Marks Clothing Co., 301 U.S. 58 (1937). 
pany nor the union cares about state lines as such, and a dispute in Pennsylvania can embitter relations in West Virginia. No single state that wanted to channel and regularize relations between employers and unions could do so on its own, at least not in the steel industry.

This argument continues to have some force even when the employer is localized within a single state, because of the national organization of unions and the tendency of separate employers to adopt parallel strategies, whether in concert or not, when confronted by a common adversary.

In addition, and quite independently, the sort of argument that properly underlies Darby ${ }^{158}$ is relevant here as well. If labor legislation is aimed partly at increasing the bargaining power of unions and improving the conditions of workers, then it is at least plausible to suppose that it will raise labor costs, just as a minimum wage does. (We may hope that productivity gains from industrial peace and good feelings will more than compensate. But Congress is not required to assume that this is the best of all possible worlds.) In that case, there is just the same disincentive to a state to enact labor legislation on its own as to enact a minimum wage. Therefore, there is the same argument as in Darby for federal power.

b. United States v. Sullivan, Pharmaceuticals, and Consumer Protection. If $N L R B$ v. Jones \& Laughlin must be justified without reliance on the argument that Congress can regulate whatever affects the movement of goods across state lines, so must United States $v$. Sullivan ${ }^{159}$ be justified without reliance on the idea, also rejected in our discussion of Katzenbach v. McClung, that Congress can regulate all behavior involving goods that have crossed state lines. Sullivan upheld the conviction of a Georgia pharmacist for failing to put a federally required label on a box of pills that he sold to a local customer. The pills had originally come from outside Georgia, but Sullivan had bought them from a Georgia supplier. When he resold a portion of them at retail he put them in a new container, which he was convicted for labeling inadequately.

Of course, it is possible that the precise result in Sullivan is not justifiable at all. So let us take the case in stages. There is surely good reason for federal drug (pharmaceutical) regulation at a general level. Most obviously, this is an area that requires great concentrations of scientific expertise. Few states could afford anything

158. See supra section III.B.2.

159. 332 U.S. 689 (1948). 
like the federal Food and Drug Administration (FDA), especially if they had to support also their own Environmental Protection Agency, their own Occupational Safety and Health Administration, and so on. Practically speaking, the states are incompetent.

Furthermore, it would be a tremendous waste of resources to duplicate the FDA and similar agencies in every state even if the states could somehow support them. This argument about the wastefulness of duplication is not strictly an argument from incompetence, but it seems fully in keeping with our general approach of allowing the federal government to facilitate state choices. The problem of drug regulation is different from many other subjects of regulation, in that there are virtually no variations in relevant "local conditions" from state to state. This means there can be great economies of scale in the decisionmaking process without any loss in the appropriateness of the results to local conditions, and with greatly diminished likelihood that any state's preferences are being seriously interfered with. Despite some divergence in the way state legislatures would handle such issues as access to novel drugs or the required detail in labeling, almost all states would probably concede that the general benefits to both manufacturers and consumers of uniform regulation justify federal intervention.

It might still be suggested that the federal government should limit itself to gathering information and disseminating that information to the state governments, which can then decide for themselves what drugs to permit or not, and under what conditions. One difficulty with this suggestion is that even to understand the "information" requires considerable expertise, so leaving even this much to the states would create a need for costly and duplicative state regulatory bureaucracies. Another difficulty is that drug companies will find themselves confronted by a host of overlapping and partially inconsistent requirements on the form of delivery of drugs, packaging, labeling, warnings, and so on.

This point about firms that sell in many states is relevant to much more than the pharmaceutical industry. It touches, at least, packaging and safety requirements for consumer products of all kinds. I have argued in another context - where the question was the scope of the dormant Commerce Clause - that the mere existence of divergent state regulations, even if that divergence makes life more complicated for firms doing an interstate business than it would otherwise be, is not a constitutional problem. ${ }^{160}$ That still

160. See Regan, supra note 77 , at $1177,1179,1187$. 
seems to me correct. If the divergence in state regulations reflects real variation in state evaluations of various costs and benefits, and if there is no other reason for federal regulation, then divergence is just what our system calls for. To forcibly harmonize state laws, whether by judicial or congressional action, for the convenience of interstate firms would be inconsistent with the spirit of our federalism. On the other hand, divergent regulations may not reflect any important differences in the views of the states. Especially where we are dealing with things like packaging and labeling requirements of fairly ordinary products like breakfast cereals, it is quite possible that every state, or almost every state, would prefer uniform regulation to nonuniform, even at the cost of not having exactly the provisions they would have come up with on their own. Where Congress plausibly concludes this is the case, the obvious mechanism for achieving coordination between the states is regulation by the federal government.

Once we have an argument for federal standards, whether as an efficient use of expert resources or in the interest of uniformity as such, there are clear advantages to federal enforcement. Pharmaceuticals, food, and other products move around from state to state as they proceed from the manufacturer to the consumer. It seems appropriate that the enforcement of standards for safety and proper labeling should be allocated to an entity whose territorial jurisdiction allows it to inspect the goods at any point or points in their travels. ${ }^{161}$

Does all of this justify the actual result in Sullivan - the conviction of a local druggist, who did not even buy the pills in interstate commerce, for misbranding by omitting a required label on the pills when he put them into a brand new container for local retail sale? Probably so. Once we have a justification for federal standard setting and for federal enforcement of the standards while the goods are still being readied for interstate shipment or still in the process of shipment or still packaged as they were shipped, ${ }^{162}$ it is obviously the most efficient use of resources to allow federal enforcement even with regard to the final transactions, like Sullivan's. ${ }^{163}$ Read-

161. Actually, the efficiencies of federal inspection are themselves a further argument for uniform federal standards, though not an argument that would carry the day on its own in my mind.

162. See McDermott v. Wisconsin, 228 U.S. 115, 136 (1913).

163. What if Georgia had passed a law specifically denying any interest in the enforcement of drug safety standards against local druggists? Could federal enforcement still proceed? Perhaps so, on the ground that the misbranded pills could still easily move across state lines and even do damage because of the misbranding in another state, after an illegal transfer to another consumer. 
ing very charitably, we could even find this argument in the Court's opinion in Sullivan.

The Sullivan opinion, aside from distinctly unpersuasive reliance on the precedent of McDermott $v$. Wisconsin, 164 identifies consumer protection as Congress's purpose and says Congress must be able to regulate drugs right up to their receipt by the final consumer if the purpose is to be fully achieved. As David Engdahl has pointed out, this appears to be improper bootstrapping. ${ }^{165}$ As of 1948, it was assumed that Congress could put whatever conditions it chose on the movement of goods across state lines, and it was entitled to do so with whatever purpose it chose, including consumer protection. But from the fact that Congress is entitled to have the purpose of consumer protection when it exercises the fundamental power to regulate state-line crossing, it does not follow at all that Congress may do whatever else may be necessary to achieve fully this protective purpose. So far Engdahl is correct.

But if we forget about Congress's supposed power to impose conditions ad libitum on line crossings, and operate with a better general approach to the commerce power, we get an argument that extends further without involving any fallacy. I have argued that Congress has the power to pass much consumer protective legislation because this is something the states generally want done that Congress can often do more efficiently. I have suggested further that once the federal government has undertaken the most extensive portion of the bureaucratic operations for pursuing this purpose - the standard setting and the enforcement as to commerce that is unquestionably interstate - it makes sense for the federal government to be able to pursue the basic protective purpose in any direction. It even makes sense for the federal government to be able to apply its standards to drugs that have never left the state of their manufacture, without troubling about any other artificial connections to commerce. This, as I say, is the charitable reading of the opinion in Sullivan.

One last observation about federal consumer protection. One of the standard arguments in favor of federal drug regulation and other product safety regulation has been that it promotes consumer confidence in goods bought in interstate commerce and thus pro-

164. 228 U.S. 115 (1913). McDermott involved goods which had not been repackaged since their interstate shipment.

165. See David E. Engdahl, Requiem for Roth: Obscenity Doctrine Is Changing, $68 \mathrm{MrCH}$. L. REv. 185, 218-19 \& n.176 (1969). 
motes demand. ${ }^{166}$ We have seen that the bare prospect of increasing interstate flows of goods is not an adequate justification for federal intervention. But consumer confidence, if it is not misplaced, is desirable, and it seems plausible to suppose that most or all states would wish to encourage it. Still, we must ask whether the federal government is better positioned to promote consumer confidence than the states.

One possibility is that consumers just are more reassured by the existence of federal regulation than by state regulation. Whether they are is an interesting question of our political sociology. If we have come so far toward being a unitary nation that a majority of the people systematically expect the federal government to do a better job of regulating things like pharmaceuticals, that is itself an argument for federal power. It is an argument with something of a bootstrap quality, but a genuine argument nonetheless. It means the federal government can achieve something the states alone cannot achieve. Of course, it may be that if people have more confidence in federal regulation, that is because they unreflectively perceive some of the reasons we have already discussed why the federal government may be able to do a better job. Or it may just be that people have come to rely on federal regulation because so much regulation in these areas has been federal. There is a special irony here because the original involvement of the federal government may have been largely attributable to doubts about the legal competence of the states to regulate goods that were "in" interstate commerce or still in their "original packages."167 So even though the Court in the first decades of this century was more dubious about federal power than we have been since 1937, their mistaken theory of "dual federalism," which asserted the mutual exclusiveness of federal and state regulatory domains, may have contributed to the creation of cultural expectations that in some areas now help to justify a much more extensive federal power than they would have approved.

c. Environmental Law. Most of the major themes we have encountered are relevant to environmental legislation, the last area I want to consider in this illustrative survey.

166. See Vincent A. Kleinfeld, Reflections on the Miller Amendment, 4 FOOD DRua Cosm. L.Q. 43, 57 (1949).

167. The seizure section of the Food and Drugs Act of 1906, ch. 3915, 34 Stat. 768 (codified at 21 U.S.C. $\S 14$ (1934)), applied only to goods "being transported" or in the "original unbroken packages." 
First, threats to air and water quality are no respecters of state lines. The same is true of many birds and animals, another subject of what we think of as environmental regulation. Effluents are carried by air and by aquifer to points far from where they originated. So in one respect, the problem of protecting environmental quality is like the problem of raising agricultural prices in Wickard. The causes are not the same, but the consequence is: individual states are to some extent flatly incapable of adequately regulating their own environments by their own efforts. It is unlikely that the states find themselves in a pure prisoner's dilemma with respect to any particular sort of environmental threat, either because, in some cases, the local benefits of regulation are substantial, or because, in other cases like acid rain, the costs of nonregulation are almost entirely external but the situation is not reciprocal. But even where there are substantial local benefits from regulation, there may be some prisoner's dilemma-like aspects to the situation, when we consider state decisions about just how or how stringently regulation is to be pursued. Of course, in those cases in which the costs of nonregulation are primarily external, we have a classic situation where the "harmony of the United States may be interrupted."

Environmental regulation also requires extensive scientific expertise, which, as we have seen, is a reason for finding a federal regulatory power. In addition, there is the same sort of argument as in Darby: states may be reluctant to impose costly environmental regulation on local businesses, for fear of handicapping them in interstate competition. ${ }^{168}$

I suspect there is very little federal environmental legislation that cannot be plausibly justified by one or more of these arguments. But if there are examples - say, the protection of some localized and nonmigratory endangered species against a threat posed by some activity which does not compete in interstate markets - then there is still the possibility I mentioned much earlier of arguing that supervision of our natural heritage is one of the "general interests of the union."

If my arguments, sketched so quickly as they apply to environmental law, are beginning to seem boringly repetitive, that suits me well, and that is why I am going to stop here. The basic ideas are simple and straightforward. They should always have been unconsciously present to anyone thinking about the commerce power. The more quickly they seem familiar, the better.

168. See supra section III.B.2. 
The reader should not let this sense of familiarity lull her into forgetting how different my approach is, in its fundamental orientation, from the currently established modes of arguing for the existence of federal power, all of which begin and end with the question "How can I assert some connection with some state-line crossing?" This question is not a bad place to begin the inquiry, if we are looking for reasons why some problem might be beyond the practical power of the states to deal with individually. But it is not where the inquiry should end.

\section{Summary, AdDENDA, AND AN UnSCIENTIFIC PostsCript}

I do not propose to summarize in the sense of listing the general interests of the union I have identified or the modes of arguing from state incompetence. I want to avoid all appearance of claiming exhaustiveness for my survey. On the other hand, I do want to rehearse the basic structure of the two main sorts of argument for federal power, so that I can add a few very schematic clarifications that did not fit naturally into the preceding discussion.

"General interests of the union" are interests that belong to the nation as such. They are not merely interests common to the states or goals Congress happens to approve. Congress is entitled to pursue the general interests of the union if the states are incapable of pursuing them effectively, or if the states are indifferent or opposed to them. In effect, Congress may pursue the general interests of the union whenever it can pursue them more effectively than the states are in fact pursuing them, whatever the reason for the states' failure.

In contrast, when the argument for congressional power does not involve a general interest of the union, but depends solely on state incompetence, Congress's role is that of a facilitator of state choices, and at least one state must want whatever goal Congress is pursuing.

Now for the additional, schematic comments:

(1) In the pure "state incompetence" case, how many states must want what Congress is doing? The answer depends on just what sort of incompetence is involved. In some cases, such as Darby, I have suggested the incompetence results in part from membership in the federal union. In such cases, it seems to me enough in principle if one state wants Congress to intervene. The idea is that in compensation for undertaking the incapacity associated with membership in the union, the state is entitled to at least a chance at federal relief. As a practical matter, no solitary state is 
likely to get what it wants from Congress. But Congress is free to intervene if for some reason it chooses to. At the other extreme, I have suggested that Congress may intervene where no state is truly incapable, but where federal regulation is the most efficient way of achieving harmonization on topics where it seems likely that most or all states prefer uniform regulation. Here we cannot be precise about the required number of states, but it seems that federal intervention should be desired by a substantial majority.

(2) Suppose a state is "incapable" of passing some kind of legislation, say gun-control legislation, because of the political influence of some interest group, say the National Rifle Association. Does that count as state incompetence for purposes of my argument? ${ }^{169}$ That depends on whether a general interest of the union is involved. If no general interest is involved, then this does not count as state incompetence. The decisions of the state legislative process represent the state's choices, and Congress should not look behind them - unless perhaps the situation is so extreme that we would be tempted to make an imaginative use of the Republican Form of Government Clause. ${ }^{170}$ On the other hand, if there is a general interest of the union involved, then the state's failure to act may be thought of, if we choose, as resulting from incapacity. What is certain is that it results either from incapacity or from motivation that is "wrong" in being insufficiently favorable to the general interest, and it does not matter which. In pursuing a general interest, Congress may act if the states fail to, for whatever reason.

(3) I should make it clear that all of my arguments are about how to interpret the Commerce Clause insofar as it is in need of interpretation. Over the years, we have expanded the Commerce Clause far beyond any plausible view of its "literal meaning," and I am concerned to figure out just how far beyond the literal meaning we should go. I do not propose that we should use my approach to subtract from the literal meaning, if there should happen to be cases where the literal meaning goes beyond what could be justified by my arguments. I have argued, of course, that we should be careful about just what the "literal meaning" includes. I suggested in connection with the "toll-gate" power that a sixty-year history of misguided Commerce Clause argument has encouraged us to see as "literal" a meaning that is not remotely so. On the other hand, if we think that, say, regulating fraud in interstate securities transac-

169. This question was brought to my attention by Vince Blasi.

170. U.S. CONST. art. IV, $\$ 4$. 
tions is within the literal meaning - a considerably more plausible claim - then Congress has the power to regulate those transactions whether the arguments I have discussed generate that conclusion or not. ${ }^{171}$

(4) Finally, one might object that insofar as my theory sometimes allows Congress to act only in response to the states' wishes, it leaves us with something less than a government of the people of the United States. It leaves us too much in the situation under the Articles of Confederation. ${ }^{172}$ The short response is that with regard to general interests of the union, Congress need not be guided by the states' choices, even if it arguably should not intervene in cases in which the states are active and capable and Congress has nothing to add. More generally, the only way to have a "government of the people of the United States" in the fullest sense would be to accord an unlimited power to the federal government. What I am suggesting is that our traditions do not call for such a government in any fuller sense than my arguments allow.

$* * *$

This was advertised as an essay about the commerce power, not about federalism in general. My arguments cast very little light on such outstanding problems as the Indian Gaming Regulatory Act, ${ }^{173}$ the Brady Bill, ${ }^{174}$ the Motor Voter Act, ${ }^{175}$ the Religious Freedom Restoration Act, ${ }^{176}$ or the correctness of the Court's decision last term in United States Term Limits, Inc. v. Thornton. ${ }^{177}$

The Indian Gaming Regulatory Act, the Brady Bill, and the Motor Voter Act involve the issue of federal commandeering of state political and bureaucratic agencies - which is tangential to the main issue under the Commerce Clause, and which I have suggested should be viewed as arising under the Necessary and Proper Clause.

The Motor Voter Act and the Religious Freedom Restoration Act involve questions about the scope of the Enforcement Powers - which I have argued call for a different approach from the Com-

171. I do not mean to concede that the arguments I have discussed would not generate that conclusion. I think they probably would. But it is the theoretical point I want to make: The example was suggested to me by Gerald Neuman.

172. I owe this thought to Richard Briffault.

173. Indian Gaming Regulatory Act, 18 U.S.C. $\$ \S 1166-68,25$ U.S.C. $\$ \S 2701-21$ (1994).

174. Brady Handgun Prevention Act, Pub. L. No. 103-159, 107 Stat. 1536 (1994) (codified in scattered sections of 18 U.S.C. \$§ 921-25A (1994)).

175. National Voter Registration Act of 1993, 42 U.S.C. § 1973gg (Supp. V 1993).

176. Religious Freedom Restoration Act, 42 U.S.C. $\$ \S 1988,2000$ bb (Supp. V 1993).

177. 115 S. Ct. 1842 (1995). 
merce Clause because the Reconstruction Amendments embody substantive policy choices meant to supersede state policies. This leaves open, of course, the question just what the federal policies embodied in those Amendments are, and what exactly Congress's role is in interpreting them. The Reconstruction Amendments are not a blank check for Congress to do anything it sees as promoting individual rights, any more than the Commerce Clause is a blank check for Congress to do anything that will affect the movement of goods.

Term Limits is not a traditional "federalism" case at all, though it involves a fundamental question about the structure of our government. The issue in Term Limits is not whether some power belongs to the federal government or to the states. If this were the issue, the obvious answer would be "to the states and to Congress, with state laws subject to revision by Congress, all as provided by Article I, Section 4." The real issue is whether the power to set term limits for federal offices is foreclosed to both Congress and state legislatures by the descriptions of terms and qualifications in the Constitution. I agree with the Court that it is.

I also have not discussed the spending power, the other power we have mainly turned to to accommodate the need for expanded federal lawmaking. I think an essay could be written about the spending power much like this essay about the commerce power, justifying most, if not all, of what Congress has done by reference to the general interests of the union or state incapacity. Our current theory of the spending power, while it may not be incoherent, is not much more sensible than the currently accepted theory of the commerce power. It became established at a time when it seemed that we had to choose between an unlimited spending power and a spending power limited by the faulty pre-1937 conception of the other powers. ${ }^{178}$ There should be a better approach. Incidentally, having a better theory of the spending power might make it easier to confront, though it would not solve, puzzles about how far conditions on spending may trench on state political organization ${ }^{179}$ or state legislative prerogatives. ${ }^{180}$

Finally, there are dozens of federal laws I have not discussed that present genuine Commerce Clause problems, and interesting ones. They are "beyond the scope of this essay" only because I

178. See United States v. Butler, 297 U.S. 1 (1936).

179. See, e.g., Oklahoma v. United States Civil Serv. Commn., 330 U.S. 127 (1947).

180. See, e.g., South Dakota v. Dole, 483 U.S. 203 (1987). 
must stop somewhere. If I have made my approach clear and anyone is interested, there is fertile ground for others to test the approach in further applications.

A final word. I hope it is clear to the reader that if I were forced to choose between the doctrine of Carter Coal and the doctrine of Katzenbach v. McClung, I would unhesitatingly choose the latter. Both cases are deeply misconceived, but McClung is nearer the truth, both in the results it authorizes and in its attention to the interstate ramifications of local behavior. My goal, however, has been to indicate that we can reject Carter Coal without embracing McClung. There is a middle way. 